\title{
Asymmetry and pathways of inter-hemispheric transport in the upper troposphere and lower stratosphere
}

\author{
Xiaolu Yan ${ }^{1, a}$, Paul Konopka ${ }^{2}$, Marius Hauck ${ }^{4}$, Aurélien Podglajen ${ }^{5}$, and Felix Ploeger ${ }^{2,3}$ \\ ${ }^{1}$ State Key Laboratory of Severe Weather \& CMA Key Laboratory of Atmospheric Chemistry, \\ Chinese Academy of Meteorological Sciences, Beijing, China \\ ${ }^{2}$ Institute for Energy and Climate Research: Stratosphere (IEK-7), Forschungszentrum Jülich, Jülich, Germany \\ ${ }^{3}$ Institute for Atmospheric and Environmental Research, University of Wuppertal, Wuppertal, Germany \\ ${ }^{4}$ Institute for Atmospheric and Environmental Sciences, Goethe University Frankfurt am Main, Frankfurt am Main, Germany \\ ${ }^{5}$ Laboratoire de Météorologie Dynamique (LMD/IPSL), École polytechnique, Institut polytechnique de Paris, \\ Sorbonne Université, École normale supérieure, PSL Research University, CNRS, Paris, France \\ ${ }^{a}$ formerly at: Institute for Energy and Climate Research: Stratosphere (IEK-7), Forschungszentrum Jülich, Jülich, Germany
}

Correspondence: Xiaolu Yan (yxlss_2004@hotmail.com)

Received: 5 November 2020 - Discussion started: 26 November 2020

Revised: 4 March 2021 - Accepted: 29 March 2021 - Published: 3 May 2021

\begin{abstract}
Inter-hemispheric transport may strongly affect the trace gas composition of the atmosphere, especially in relation to anthropogenic emissions, which originate mainly in the Northern Hemisphere. This study investigates the transport from the boundary surface layer of the northern hemispheric $(\mathrm{NH})$ extratropics $\left(30-90^{\circ} \mathrm{N}\right)$, southern hemispheric $(\mathrm{SH})$ extratropics $\left(30-90^{\circ} \mathrm{S}\right)$, and tropics $\left(30^{\circ} \mathrm{S}-30^{\circ} \mathrm{N}\right)$ into the global upper troposphere and lower stratosphere (UTLS) using simulations with the Chemical Lagrangian Model of the Stratosphere (CLaMS). In particular, we diagnose interhemispheric transport in terms of the air mass fractions (AMFs), age spectra, and the mean age of air (AoA) calculated for these three source regions. We find that the AMFs from the NH extratropics to the UTLS are about 5 times larger than the corresponding contributions from the SH extratropics and almost 20 times smaller than those from the tropics. The amplitude of the AMF seasonal variability originating from the $\mathrm{NH}$ extratropics is comparable to that from the tropics. The $\mathrm{NH}$ and $\mathrm{SH}$ extratropical age spectra show much stronger seasonality compared to the seasonality of the tropical age spectra. The transit time of NH-extratropicalorigin air to the $\mathrm{SH}$ extratropics is longer than vice versa. The asymmetry of the inter-hemispheric transport is mainly driven by the Asian summer monsoon (ASM). We confirm the important role of ASM and westerly ducts in the interhemispheric transport from the $\mathrm{NH}$ extratropics to the $\mathrm{SH}$.
\end{abstract}

Furthermore, we find that it is an interplay between the ASM and westerly ducts which triggers such cross-Equator transport from boreal summer to fall in the UTLS between 350 and $370 \mathrm{~K}$.

\section{Introduction}

The transport from the troposphere to the stratosphere plays an important role in determining the chemical composition of the atmosphere and hence radiative features, which can impact atmospheric chemistry and global climate. For example, ozone-depleting substances (ODSs), greenhouse gases, and aerosols in the atmosphere are mainly driven by natural and anthropogenic emissions at the Earth's surface (e.g., WMO, 2018). Although tropospheric air enters the stratosphere mainly through the tropical tropopause layer (TTL) (e.g., Holton et al., 1995; Levine et al., 2007; Fueglistaler et al., 2009), which is then transported to the global stratosphere by the Brewer-Dobson (BD) circulation (e.g., Butchart, 2014), significant contributions of air mass transport from the troposphere to stratosphere are found through other pathways, e.g., monsoons (e.g., Randel et al., 2012; Ploeger et al., 2017), quasi-isentropic transport through the extratropics (e.g., Hoor et al., 2005; Bönisch et al., 2009; Konopka and Pan, 2012), and inter-hemispheric transport (e.g., Tomas and 
Webster, 1994; Waugh and Polvani, 2000; Orbe et al., 2018; Wu et al., 2018).

Inter-hemispheric transport is important for understanding the distributions of atmospheric tracers because of the asymmetry in anthropogenic emissions between the Southern Hemisphere $(\mathrm{SH})$ and the Northern Hemisphere $(\mathrm{NH})$, with generally strongest emissions in the $\mathrm{NH}$ caused by the higher population density. For instance, the anthropogenic and long-lived greenhouse gas $\mathrm{SF}_{6}$ in the atmosphere, which is widely used in the study of transport (e.g., Maiss et al., 1996; Denning et al., 1999; Gloor et al., 2007; Patra et al., 2011; Krol et al., 2018), mostly originates from the NH (e.g., Ravishankara et al., 1993; Kovács et al., 2017). The ALE/GAGE experiment showed that nearly $95 \%$ of the reported sources of ODSs (e.g., $\mathrm{CH}_{3} \mathrm{CCl}_{3}$ and $\mathrm{CFCl}_{3}$ ) are in the NH with maxima centered around the midlatitudes (Wang and Shallcross, 2000). Besides anthropogenic emissions, natural emissions in the $\mathrm{NH}$ are different from those in the $\mathrm{SH}$ due to the asymmetry of topography and land-sea distribution between the two hemispheres. Although the source distributions of many tracers are different in the $\mathrm{SH}$ and $\mathrm{NH}$, the observed trends of the tracers are almost homogeneous in the global upper troposphere and lower stratosphere (UTLS), which suggests the key role of inter-hemispheric transport in regulating the distribution of atmospheric trace gases and maintaining the mass balance (e.g., Müller and Brasseur, 1995; Wang and Shallcross, 2000; Liang et al., 2014; Patra et al., 2014; Chen et al., 2017). Holzer (2009) found that approximately one-third of the NH extratropical surface air is transported to the SH extratropical surface. Francey and Frederiksen (2016) emphasized the importance of interannual variations in inter-hemispheric transport in explaining the sudden increase of the annual mean $\mathrm{CO}_{2}$ difference between Mauna Loa in the NH and Cape Grim in the SH during 2009-2010. The redistribution of the tracers can strongly affect the dynamical and chemical processes in the atmosphere.

A simplified model including two well-mixed boxes, one each for the $\mathrm{SH}$ and the $\mathrm{NH}$, has been extensively used to quantify the inter-hemispheric transport in previous studies (e.g., Czeplak and Junge, 1975; Denning et al., 1999; Lintner et al., 2004; Patra et al., 2009; Chen et al., 2017; Krol et al., 2018; Naus et al., 2019). Due to the strong transport barrier between the tropics and extratropics (e.g., Hoskins et al., 1985; Bowman, 2006; Kunz et al., 2011), a three-box model including the SH extratropics, tropics, and $\mathrm{NH}$ extratropics was suggested to be used in quantifying inter-hemispheric transport (e.g., Bowman and Carrie, 2002; Erukhimova and Bowman, 2006). The exchange time ( $\left.\tau_{\mathrm{ex}}\right)$ across the Equator is one common parameter for quantifying the inter-hemispheric transport and is defined by the mass balance equation derived from the difference of mean mixing ratios of tracers in the $\mathrm{NH}$ and $\mathrm{SH}$ and the net crossequatorial flux (See e.g., Jacob et al., 1987; Patra et al., 2009; Waugh et al., 2013). $\tau_{\text {ex }}$ is related to the calculation method and to the hemispheric distribution and emissions of the tracer chosen. Values of $\tau_{\text {ex }}$ range between 0.8-2.0 years based on the calculations of different models and passive tracers (e.g., Maiss et al., 1996; Denning et al., 1999; Peters et al., 2004; Patra et al., 2011; Liang et al., 2014; Yang et al., 2019).

Age of air (AoA) is another widely used variable for quantifying the inter-hemispheric transport, which provides more information compared to the inter-hemispheric exchange time $\tau_{\text {ex }}$. AoA can be derived from the age spectrum and has also been determined from observations of species with a nearly linear growth in mixing ratios such as for $\mathrm{CO}_{2}$ and $\mathrm{SF}_{6}$ (e.g., Hall and Plumb, 1994; Volk et al., 1997; Engel et al., 2009, 2017; Stiller et al., 2012; Ray et al., 2014) and from model simulations (e.g., Schoeberl et al., 2005; Garny et al., 2014; Konopka et al., 2015; Ploeger and Birner, 2016). These AoA calculations are sensitive to the tracers chosen, to the method of calculation, and to the models and reanalysis data used (e.g., Krol et al., 2018; Fritsch et al., 2019; Hauck et al., 2019; Podglajen and Ploeger, 2019; Ploeger et al., 2019). Waugh et al. (2013) estimated AoA using $\mathrm{SF}_{6}$ observations and showed that the mean AoA from the NH midlatitude surface to the SH midlatitudes surface is around 1.4 years. Orbe et al. (2016) and Chen et al. (2017) highlighted the important role of monsoon circulation in reducing mean AoA in the SH with respect to the NH. Konopka et al. (2017) and Krol et al. (2018) recently discussed an interesting asymmetry feature in inter-hemispheric transport with more effective transport from the NH surface to the $\mathrm{SH}$ than vice versa.

Many mechanisms have been proposed to drive the interhemispheric transport, including transport related to eddies and wave breaking (e.g., Czeplak and Junge, 1975; Tomas and Webster, 1994; Staudt et al., 2001), vertical convective transport (e.g., Prather et al., 1987; Hartley and Black, 1995; Denning et al., 1999; Lintner et al., 2004; Erukhimova and Bowman, 2006), seasonal modulation of the Hadley circulation related to the migration of the Intertropical Convergence Zone (ITCZ) across the Equator (e.g., Bowman and Cohen, 1997; Wang and Shallcross, 2000), and monsoon circulation (e.g., Orbe et al., 2016; Chen et al., 2017). Zonally resolved results showed that westerly ducts over the Pacific and Atlantic regions are favored regions for the inter-hemispheric transport and redistribution of the atmospheric compositions (e.g., Webster and Holton, 1982; Tomas and Webster, 1994; Waugh and Polvani, 2000; Staudt et al., 2001; Ratnam et al., 2015; Francey and Frederiksen, 2016). The westerly ducts are strongest in boreal winter and affected by the El NiñoSouthern Oscillation, being stronger during La Niña periods and weaker during El Niño periods (e.g., Waugh and Polvani, 2000; Staudt et al., 2001; Dlugokencky et al., 2009; Francey and Frederiksen, 2016; Pandey et al., 2017). Although multiple mechanisms were suggested to be the generators of the inter-hemispheric transport, it is still not clear that the interhemispheric transport is driven by each mechanism independently or by the combination of different mechanisms. 
Most previous studies have focused on the interhemispheric transport from the $\mathrm{NH}$ to the $\mathrm{SH}$ in the troposphere using a two-box model based on zonal mean results, with relatively few analyses investigating the crossequatorial transport in the stratosphere (e.g., Lintner, 2003; Patra et al., 2009, 2011; Holzer, 2009). Complementary to previous studies, we intend to further examine the interhemispheric transport in the UTLS because of the global chemical, radiative, and climate effects of atmospheric species in the UTLS. The contributions, pathways, and mechanism from the $\mathrm{NH}$ extratropics and $\mathrm{SH}$ extratropics to the upper troposphere and stratosphere driven by the interhemispheric transport have not been well understood hitherto. Since anthropogenic emissions are mainly produced in the $\mathrm{NH}$, the understanding of transport from the $\mathrm{NH}$ to the tropics, the SH, and the global upper troposphere and stratosphere is particularly important. In this study, we address the following questions:

1. How large are the contributions from the NH extratropics, SH extratropics, and tropics to the upper troposphere and stratosphere, and what is the respective transit time?

2. Which regions are favored regions (pathways) for the inter-hemispheric transport from the $\mathrm{NH}$ extratropics to the SH extratropics?

3. What is the underlying mechanism in terms of dynamics and circulation and in relation to the mechanisms proposed in past studies?

We investigate the transport from the $\mathrm{NH}$ to the $\mathrm{SH}$ and vice versa using the simulations from the three-dimensional Chemical Lagrangian Model of the Stratosphere (CLaMS) with the atmospheric source regions divided into three domains (the $\mathrm{SH}$ extratropics, the tropics, and the $\mathrm{NH}$ extratropics). We quantify the contributions and age spectra from these different regions to the upper troposphere and stratosphere using zonally averaged results for the global view. Particularly, we focus on quantifying the interhemispheric transport and characterizing the pathways of inter-hemispheric transport by analyzing zonal mean and zonally resolved model output. Section 2 presents data and methods for our analyses. In Sect. 3, we diagnose the seasonality of transport from different source regions. We explore the pathways of inter-hemispheric transport in Sect. 4 and discuss our findings in Sect. 5 before closing with a summary of the key results in Sect. 6.

\section{Data and methods}

In this study, the surface is divided into three boxes to investigate the inter-hemispheric transport, which are the $\mathrm{NH}$ extratropics $\left(30-90^{\circ} \mathrm{N}\right), \mathrm{SH}$ extratropics $\left(30-90^{\circ} \mathrm{S}\right)$, and tropics $\left(30^{\circ} \mathrm{S}-30^{\circ} \mathrm{N}\right)$. The threshold of $30.0^{\circ}$ is a common choice to separate tropics from extratropics (e.g., Fueglistaler et al., 2011) as it divides the Earth's surface into equal areas of both regions and further coincides approximately with the horizontal transport barriers of the subtropical jet cores. We calculate age spectra and the air mass fraction (AMF) to study transport from the surface of the NH extratropics, SH extratropics, and tropics using the CLaMS model. CLaMS is a Lagrangian chemistry transport model with trace gas transport driven by horizontal winds and total diabatic heating rates from reanalysis data (e.g., McKenna et al., 2002; Konopka et al., 2004; Pommrich et al., 2014).

We apply the boundary impulse (time-)evolving response approach to calculate the age spectrum $G$ following Ploeger and Birner (2016), which is based on the boundary impulse response method (e.g., Holzer et al., 2003; Haine et al., 2008; Li et al., 2012; Orbe et al., 2016) but evolves over time in a transient simulation using quasi-observational winds. Multiple tracer pulses are released in the boundary source region $\Omega_{i}$, with $i$ labeling the source domain (e.g., NH extratropics, $\mathrm{SH}$ extratropics, tropics). The passive tracer with mixing ratio $\chi_{i}$ at location $r$ and time $t$ related to the mixing ratio $\chi_{0}(t)$ from the boundary surface of different source regions, which defines the AMF from source regions, can be expressed as (e.g., Waugh and Hall, 2002; Orbe et al., 2013; Ploeger et al., 2019)

$\chi_{i}(r, t)=\int_{0}^{\infty} \mathrm{d} \tau \chi_{0}\left(\Omega_{i}, t-\tau\right) G\left(r, t \mid \Omega_{i}, t-\tau\right)$.

The age spectrum is calculated from 120 pulses of inert trace gas species from 3 source regions, with 40 different species pulsed in each region. These pulse tracers approximate a delta distribution lower-boundary condition $\chi_{0}^{j}$ $\left(\Omega_{i}, t\right)=\delta\left(t-t_{j}\right)$ with $j=1, \ldots, 40$ defining tracer pulses at source times $t_{j}$. The pulse tracer mixing ratios are set to 1 in the boundary layer of the source region for $30 \mathrm{~d}$ and are set to 0 in the boundary layer outside of the initialization region in every time step. The first 24 different species $(j=1, \ldots, 24)$ with transit time less than 2 years are pulsed every month. The other 16 different species $(j=25, \ldots, 40)$ are pulsed every 6th month (e.g., 25th species in the 30th month and 26th species in the 36th month). Hence, all species have been pulsed after 10 years of model simulations and are reset to 0 in the whole atmosphere and pulsed again subsequently thereafter.

Therefore, the model simulations provide a monthly resolution age spectrum for transit times shorter than 2 years and a semi-annual resolution age spectrum for longer transit times. The integration of the spectrum over time generally yields a value less than 1 and AoA is young-biased caused by the truncation of the simulations at 10 years. Therefore, we calculate the mean AoA for each source region by normalizing the age spectrum to unit norm: 


$$
\Gamma_{i}(r, t)=\int_{0}^{10} \tau G\left(r, t \mid \Omega_{i}, \tau\right) \mathrm{d} \tau / \int_{0}^{10} G\left(r, t \mid \Omega_{i}, \tau\right) \mathrm{d} \tau .
$$

The details about the model setup and the calculation of age spectra from multiple pulse tracers and the mean AoA from the age spectrum can be found in Ploeger and Birner (2016) and Ploeger et al. (2019). For the purpose of our study, the pulse tracer mixing ratios are set to 0 in the boundary layer during every time step, which allows us to separate the transport contributions and pathways in the UTLS from those of transport in the boundary layer. As inter-hemispheric transport in the lower troposphere has been the focus of several past studies (e.g., Staudt et al., 2001; Orbe et al., 2015; Chen et al., 2017; Krol et al., 2018), here we focus on transport in the UTLS. Detailed comparisons with previous studies using different model setups, which are mainly focused on the inter-hemispheric transport in the troposphere (e.g., Orbe et al., 2015, 2016), will be provided later. For this study, we carried out a simulation covering the period from 1989 to 2017 with transport driven by the meteorological data from ERA-Interim (Dee et al., 2011). Due to the 10-year spin-up time for the age spectra, the model data from 1999-2017 are analyzed in the following to address the questions raised in the Introduction.

\section{Seasonality of transport}

\subsection{Seasonality of air mass fractions}

To evaluate the global contributions from the source regions, we calculate the zonally averaged seasonal mean AMFs from the boundary layer of the three source regions. In the following, we use the abbreviations of months (DJF, MAM, JJA, and SON) to represent different seasons. Figure 1 shows the seasonal variations in AMF originating from the NH extratropics, SH extratropics, and tropics during 1999-2017. The sum of the AMF over all three source regions is $\sim 1$, related to the limitation of the maximal transit time in our simulations. Note that different color bars are used for the AMF transported from each source region. The global results show that the AMFs from the $\mathrm{NH}$ extratropics to the troposphere and stratosphere are about 5 times larger than the corresponding contributions from the SH extratropics. The relative contributions of transport from the NH extratropics to the atmosphere compared to those from the tropics depend on the altitude, and they are about 10-15 times smaller than the tropical AMFs in the middle and upper troposphere and around 20-40 times smaller in the stratosphere. Although the contributions from the tropics to the UTLS are much larger than those from the NH extratropics, the annual amplitude of tropical AMFs in the UTLS is comparable to that of NH extratropical AMFs, related to the small contributions from the $\mathrm{SH}$ extratropics.
Newly pulsed air masses (younger than 3 months) from the $\mathrm{NH}$ extratropics start to cross the subtropical tropopause in boreal summer (JJA, Fig. 1g). Three months later, air masses from the $\mathrm{NH}$ extratropics are elevated to the lower stratosphere first mainly in the Asian summer monsoon (ASM) region driven by the monsoon circulation and are then transported isentropically to the tropical lower stratosphere and $\mathrm{NH}$ extratropical lower stratosphere, covering the latitude range from $30^{\circ} \mathrm{S}$ up to the Arctic regions (Fig. 1j). Later on, the $\mathrm{NH}$ extratropical air masses in the upper-tropospheric and lower-stratospheric tropics driven by the ASM are further transported to the tropical pipe and the whole $\mathrm{SH}$ in DJF and MAM (Fig. 1a and d). Note that young air masses pulsed during boreal winter and spring (DJF and MAM) are not transported to the subtropical stratosphere.

The seasonality in the transport patterns of AMFs originating from the SH extratropics is shifted by 6 months compared to those from the NH extratropics. Although the respective contributions of the SH extratropics (i.e., in DJF and MAM) show some similarities to those from the NH extratropics (i.e., in JJA and SON), there are few significant differences between transport from the $\mathrm{NH}$ extratropics and $\mathrm{SH}$ extratropics. Crossing of the subtropical tropopause for SH-extratropical-origin air happens first in austral autumn (MAM, Fig. 1e) rather than austral summer (DJF, Fig. 1b), and the overall impact of the SH extratropical boundary surface tracers on both the tropics and the high latitudes is significantly weaker. Most transport of SH-extratropical-origin tracers is inhibited by the tropopause in the subtropical $\mathrm{SH}$ during DJF (Fig. 1b) and MAM (Fig. 1e). In particular, the SH extratropical AMF in the SH lower stratosphere during austral autumn (MAM) is much smaller than the NH extratropical AMF in the $\mathrm{NH}$ lower stratosphere during boreal autumn (SON). These differences are most likely attributed to hemispheric differences in the strengths of the monsoons (e.g., Orbe et al., 2016; Chen et al., 2017) and in the strength and downward extent of the polar vortices.

Figure $1 \mathrm{c}, \mathrm{f}, \mathrm{i}$ and $\mathrm{l}$ show that the tropical surface air dominates the atmospheric composition in the global UTLS. The seasonality of the tropical contribution results from the superposition of the Hadley and BD circulations, which are schematically illustrated in Fig. 2a for DJF and Fig. 2b for JJA by using the residual mean mass streamfunction. The upwelling of the Hadley and BD circulations is shifted northward from DJF to JJA. Note the hemispheric asymmetric upwelling positions of the circulations in winter and summer. The Hadley cell upwelling is located in the SH tropics around $5^{\circ} \mathrm{S}$ during boreal winter, while the upwelling is shifted far into the $\mathrm{NH}$ subtropics to latitudes of around $20^{\circ} \mathrm{N}$ in boreal summer. Thus, the strongest contribution of the tropical surface air to the stratosphere starts in boreal winter (DJF, Fig. 1c) and peaks in MAM (Fig. 1f) as the result of the strongest positive coupling between the Hadley and BD circulations. The seasonality, in terms of relative amplitude, of the air originating from the tropics is less pronounced com- 

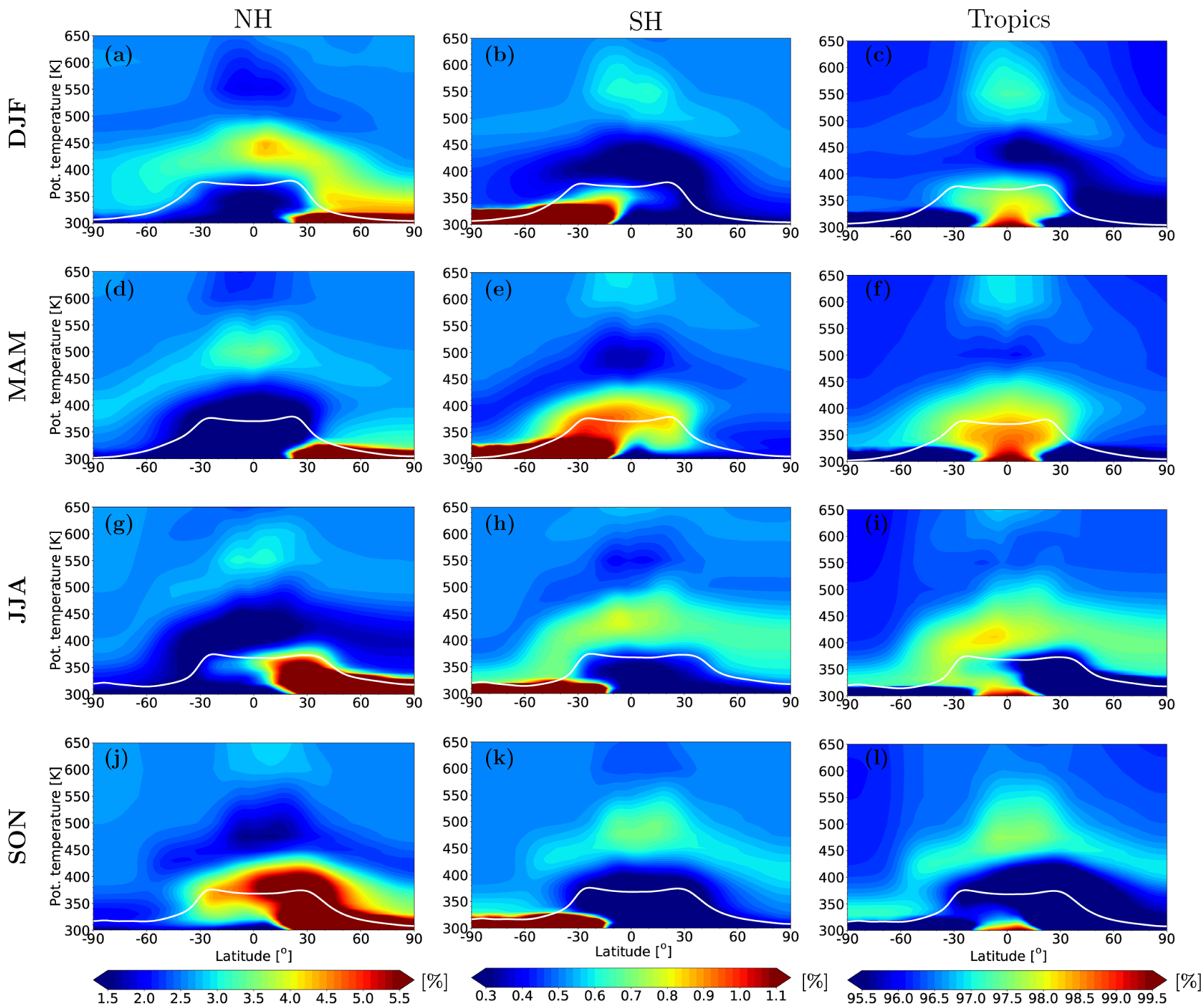

Figure 1. Climatological (1999-2017) zonal mean AMFs originated from the NH extratropics (a, d, g, j), SH extratropics (b, e, h, k), and tropics $(\mathbf{c}, \mathbf{f}, \mathbf{i}, \mathbf{l})$ for different seasons (rows). The AMFs for all three source regions add up to $\sim 1$. The white line shows the WMO tropopause.

(a)

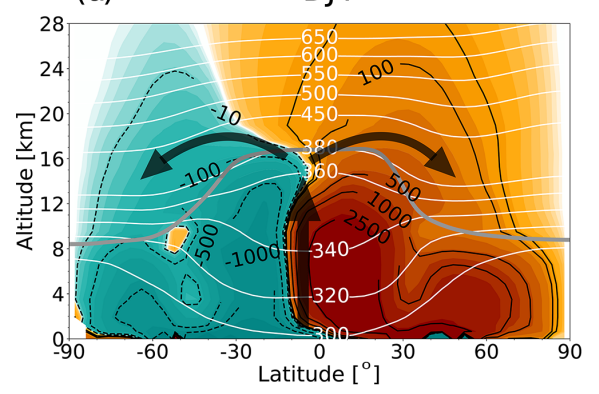

(b)

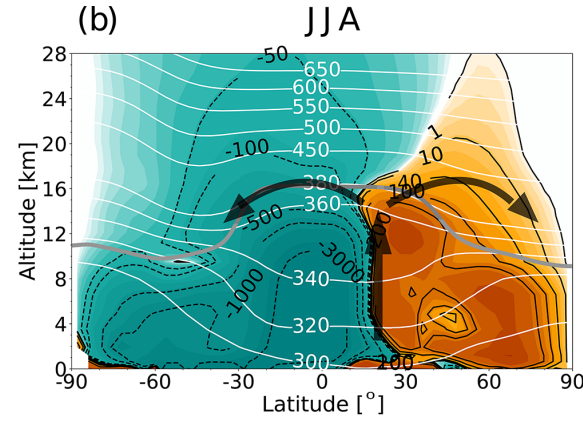

$[\mathrm{kg} / \mathrm{m} / \mathrm{s}]$

Figure 2. Climatology (1999-2017) of the residual mean mass streamfunction (color shading with a subset of values highlighted in black contours). The grey line shows the WMO tropopause. White contours show potential temperature levels in kelvin. The thick black arrows illustrate the upwelling of the Hadley circulation and the shallow branch of the BD circulation (around $400 \mathrm{~K}$ ). 

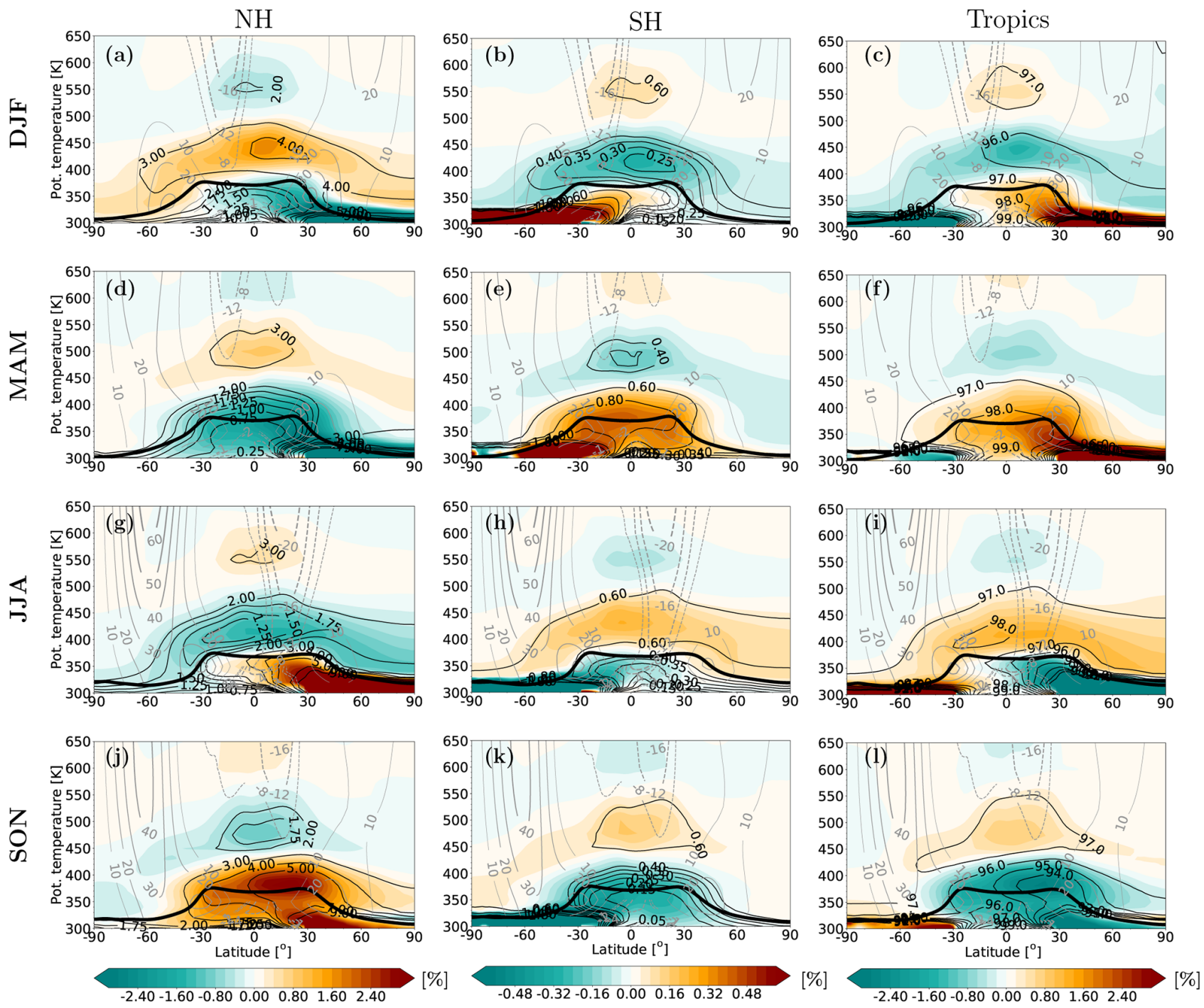

Figure 3. Climatological (1999-2017) zonal mean AMF departure from the annual average. The absolute AMF contributions from Fig. 1 are shown as black contours. Grey contours show the mean zonal winds. The thick black line is the WMO tropopause.

pared to that from the $\mathrm{NH}$ extratropics and $\mathrm{SH}$ extratropics. The evolution of the tropical source air shows similar patterns to those from the SH extratropics. The transport pattern is significantly different from the transport of the $\mathrm{NH}$ extratropical source air. It is especially remarkable how the northward shift in the boreal summer Hadley cell weakens upward transport from the tropics during JJA and SON (Fig. 1i and 1) while favoring upward transport from the $\mathrm{NH}$ surface (Fig. 2b), whereas this effect is much weaker during the austral summer (DJF and MAM, Fig. 1c and f).

To further explore the seasonal variations of transport from the boundary layer, we remove the annual mean of the contributions from each source region. These seasonal anomalies of climatological zonal mean AMF are shown in Fig. 3 from the NH extratropics (Fig. 3a, d, g and j), SH extratropics (Fig. 3b, e, h and k), and tropics (Fig. 3c, f, i, and l). Note the different color bar for $\mathrm{NH}$ extratropical air and SH extratropical air. Clearly, the amplitude of the AMF seasonal cycle in the global UTLS originating from the $\mathrm{NH}$ extratropics is comparable to that from the tropics and about 5 times larger than that from the $\mathrm{SH}$ extratropics. The transport features of the NH extratropical AMF anomalies starting from boreal summer (JJA) again show similar patterns to those from the SH extratropics starting from austral summer (DJF), with a shift of 6 months and much smaller absolute anomalies, although the relative anomalies are comparable.

There are also few new structures in Fig. 3 compared to the absolute contributions in Fig. 1. A pronounced positive anomaly in the lower stratosphere over the $\mathrm{NH}$ extratropics and tropics in SON (Fig. 3j) is related to the isentropic transport directly above the ASM region after the elevation of $\mathrm{NH}$ extratropical air by the monsoon circulation, which 
again suggests that the tropospheric air in the NH extratropics is mainly transported to the $\mathrm{NH}$ and tropical lower stratosphere via the ASM circulation. The positive anomaly of $\mathrm{NH}$ extratropical air also crosses the Equator and extends southward into the $\mathrm{SH}$ subtropics from the middle troposphere to the stratosphere. We will further explore the mechanism driving the inter-hemispheric transport in the UTLS using zonally resolved data later. Another striking feature is the negative anomaly of the $\mathrm{NH}$ extratropical air mass in the layer around $320 \mathrm{~K}$ in the $\mathrm{NH}$ during boreal autumn (Fig. 3j). This signature might be associated with the combination of less convective activity in boreal autumn in the NH extratropics; with the suppression of horizontal transport from the subtropical troposphere in the layer around $320 \mathrm{~K}$; or, finally, with the southward movement of the Hadley cell, enhancing isentropic, poleward transport from the tropics and across the still-weak summer-autumn jet (see Fig. 31).

In contrast to the $\mathrm{NH}$ case, the anomaly for $\mathrm{SH}$ extratropical air masses shows negative values almost throughout the SH extratropical lower stratosphere during austral autumn (Fig. 3e). This difference to the NH extratropical air (Fig. 3j) is mainly related to the weak convection and the strong inhibition (strong zonal jet) of horizontal transport from the subtropical region in the $\mathrm{SH}$ during austral autumn (MAM). In the $\mathrm{NH}$, the tropopause barrier is weak and upward motion over the ASM region is strong, and a substantial amount of $\mathrm{NH}$-extratropical-origin air can be transported to the lower stratosphere driven by monsoon circulation.

\subsection{Seasonality of age spectrum and age of air}

In Sect. 3.1, we quantified transport using the AMF, which measures the contribution from different source regions to the air composition in the UTLS. In this section, we provide a complementary view of transport in terms of the age spectrum derived from the same simulations and for the same source regions as in Sect. 3.1. Figures 1 and 3 show that strong isentropic transport across the tropopause occurs in the layer around $360 \mathrm{~K}$. Hence, we consider the age spectrum at $360 \mathrm{~K}$ as a reference location for the UTLS.

The age spectra of air from the NH extratropics, SH extratropics, and tropics are illustrated in Fig. 4. Note the different color bars used for the three source regions. The transport seasonality is evident for the NH-extratropical- and $\mathrm{SH}$ extratropical-origin air, even stronger than the seasonality for the age spectra with tropical origin, which is consistent with the results based on the AMF (Fig. 1). The first peak of the NH extratropical age spectrum during boreal summer and autumn (Fig. $4 \mathrm{~g}$ and $\mathrm{j}$ ) is a very strong signature compared to the SH extratropical age spectrum during austral summer and autumn (Fig. 4b and e), which means that much more young air can be expected in the NH compared to the SH. The age spectrum of NH-extratropical-origin air always shows large PDF values at young transit times during boreal summer and nearly 0 during boreal winter, which suggests that the pollu- tants from the NH extratropics are transported to the global UTLS primarily during boreal summer.

The age spectrum and mean AoA from the SH extratropics show a lot of similarities to those from the NH extratropics shifted by 6 months. However, NH-extratropical-origin young air ( $<6$ months) shows peak values around the ASM region (Fig. $4 \mathrm{~g}$ and $\mathrm{j}$ ). The flushing of the $\mathrm{NH}$ lowermost stratosphere with $\mathrm{NH}$-extratropical-origin air during boreal summer and autumn (JJA and SON) is more pronounced compared to the flushing of the $\mathrm{SH}$ lowermost stratosphere with SH-extratropical-origin air during austral summer and autumn (DJF and MAM). The mean AoA shows that interhemispheric transport proceeds faster from the $\mathrm{SH}$ extratropics to the $\mathrm{NH}$ extratropics than from the $\mathrm{NH}$ extratropics to the SH extratropics, in qualitative agreement with results found by Konopka et al. (2017, their Fig. 5) related to the weaker barrier along the jet in the NH (see Fig. 3) which allows faster horizontal transport. Another important asymmetry is that, with exception of MAM, the mean AoA is always older in the SH than in the NH for all other seasons and for all source tracers. This is mainly a consequence of hemispheric differences in the wave-driven eddy mixing, being stronger in the NH throughout the year (Rosenlof, 1995; Konopka et al., 2015).

Figure 5 confines the global age spectrum shown in Fig. 4 to partial age spectra at the latitude of $60^{\circ} \mathrm{N}$, which defines the spectra from individual source region without normalization to 1 . The age spectrum for the $\mathrm{NH}$-extratropical-origin air (Fig. 5a) shows multiple peaks caused primarily by the interplay between Hadley and BD circulations. The Hadley cell upwelling is shifted to the NH subtropics during boreal summer, which is the season favoring upward transport from the NH surface, and peaks in the spectrum are related to air originating at the NH surface in early summer. The youngest peak is in JJA at transit times of around 2 months as a result of an "in-phase" interaction between the Hadley and the lower branch of the BD circulation. The respective first peaks in the following seasons are shifted accordingly, which suggests that most of the air in the $\mathrm{NH}$ high-latitude region with its origin in the NH extratropical boundary layer is emitted during boreal early summer. Although the tropical upwelling has its maximum in boreal winter and spring, it does not significantly transport the $\mathrm{NH}$-extratropical-origin air to the high-latitude lower stratosphere. This is mainly because the Hadley cell supports such a transport pathway rather in summer than in winter and spring (Fig. 2). In addition, transport of the NH-extratropical-origin air to the high latitudes reaches its maximum in boreal autumn. Note that the second peak in JJA resulting from the $\mathrm{NH}$-extratropical-origin air is higher than the first peak. The mean AoA shows the youngest value in boreal autumn (SON) and oldest value in boreal spring (MAM).

Although the structure of the age spectrum of the SHextratropical-origin air (Fig. 5b) also includes multiple peaks like that from the $\mathrm{NH}$ extratropics, its total contribution is al- 

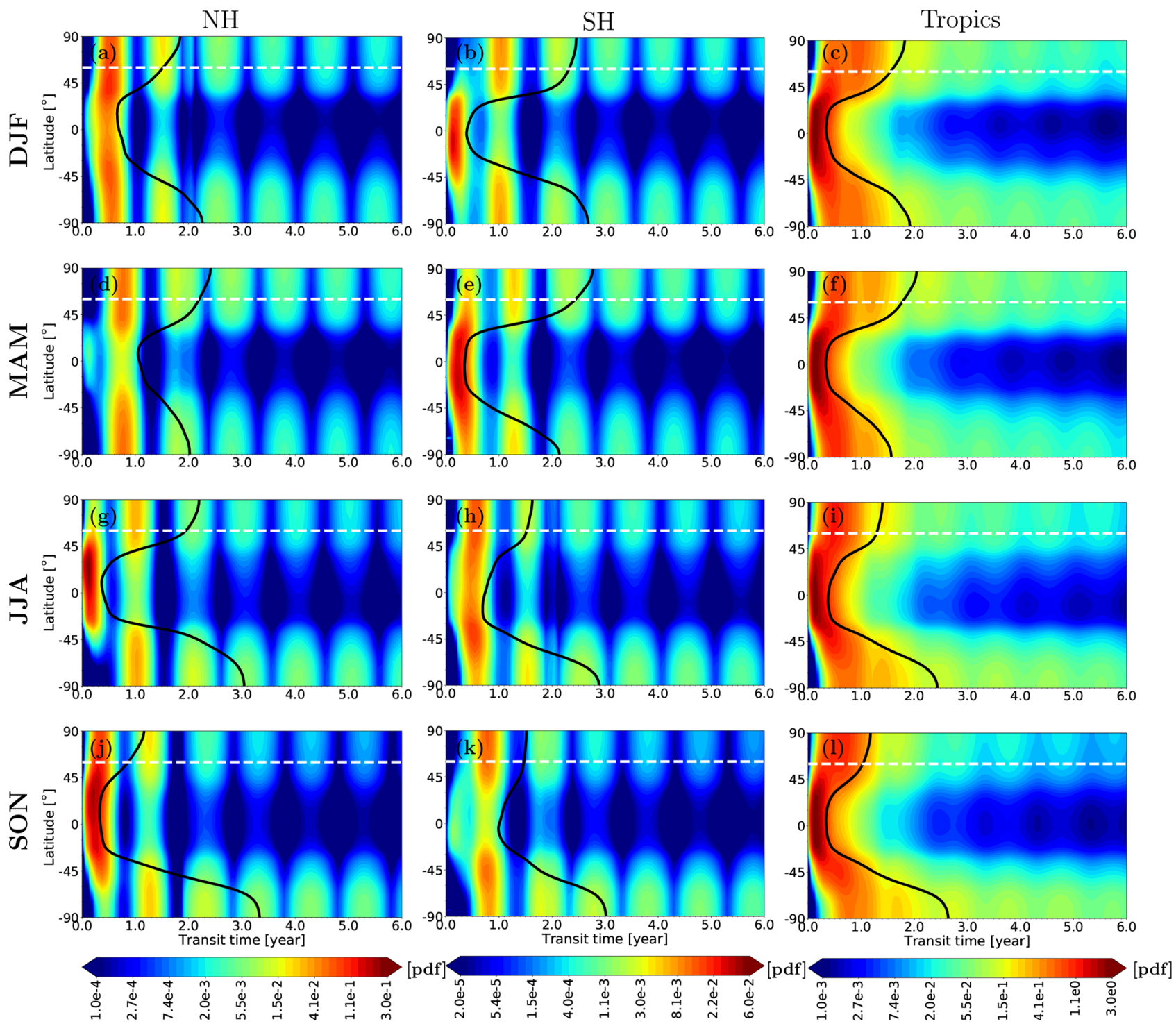

Figure 4. Age spectra as (partial) transit time probability density functions (PDFs), calculated for air originating from three source regions: NH extratropics, SH extratropics, and tropics. Age spectra are shown at $\theta=360 \mathrm{~K}$ (destination region) for all seasons. For each season, the sum of the integral of the age spectra over all three source regions (i.e., over all partial contributions) is $\sim 1$, with deviations caused by our approximation limiting the maximal transit time to 10 years. The black line shows the mean AoA as derived from the age spectrum. White dashed line marks $60^{\circ} \mathrm{N}$ latitude.

most 10 times smaller than the respective contribution from the NH extratropics. The first peak in age spectra in each season from MAM to DJF is delayed by around 3 months accordingly, which again suggests that the main contribution from the SH extratropics originates in austral summer. The mean AoA from the SH extratropics is older than that from the NH extratropics during each season except in JJA.

The age spectrum of tropical origin (Fig. 5c) shows by far the highest partial contribution (10 and 100 times larger than that of the $\mathrm{NH}$ and $\mathrm{SH}$, respectively). Unlike the age spectrum of the NH-extratropical- and SH-extratropical-origin air, the tropical age spectrum in JJA and SON has only one clear peak at transit time around 6 months. During DJF and MAM the tropical age spectrum shows more a multimodal shape with the primary peak at transit time around 6 months and a secondary peak delayed by a few months. The first peak might be related to the Hadley and BD circulations combining with the rapid isentropic transport. The second peak shows a similar transit time to the air originating from the $\mathrm{SH}$ extratropics, which suggests that the peak might be driven by recirculation within the shallow branch of the BD circulation. The age spectra along $60^{\circ} \mathrm{S}$ on the $360 \mathrm{~K}$ isentropic surface shows similar patterns with a 6-month shift and different amplitudes (not shown). 

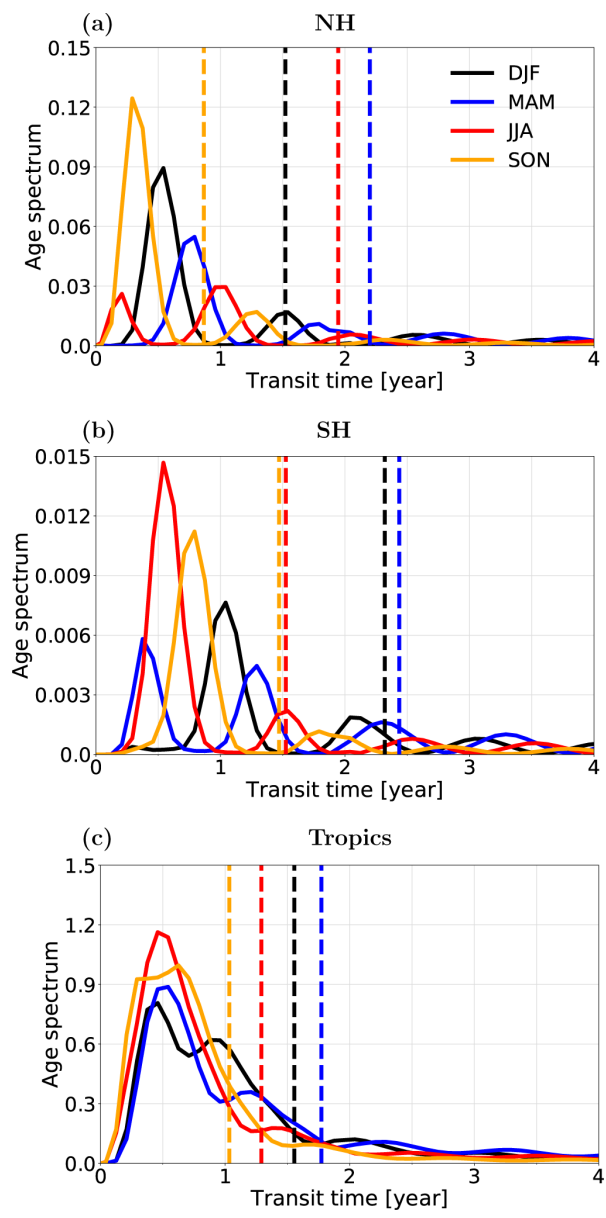

Figure 5. Partial age spectra of the air with the origin in $\mathrm{NH}$ extratropics (a), SH extratropics (b), and tropics (c) calculated at $360 \mathrm{~K}$ along $60^{\circ} \mathrm{N}$ (destination region). Different colors represent different seasons. Vertical dashed lines indicate the mean AoA. Note different ranges of the $y$ axis (tropics $=10 \times \mathrm{NH}$; $\mathrm{NH}=10 \times \mathrm{SH}$ ), which quantify relative differences of the considered source regions.

Finally, to get the global view of the mean transit time seasonality from the three source regions, we calculate for each season the mean AoA from the respective age spectrum using Eq. (2). The mean AoA for each source region and season with and without the annual mean removed is compared in Fig. 6. A similar picture emerges of the well-known seasonality and hemispheric asymmetries of the Hadley and BD circulations (e.g., Konopka et al., 2015, and citations therein). While the seasonality of the tropical upwelling dominates the tropical features, the strength of isentropic poleward transport and polar vortices explains the patterns at high latitudes. The highest amplitude in the AoA anomalies for NH sources can be diagnosed in the polar $\mathrm{SH}$, and vice versa for the $\mathrm{SH}$ sources in the polar NH. The amplitude of seasonality in the tropics, especially of the air originating in the tropics, is much smaller compared to that in the $\mathrm{NH}$ extratropics and SH extratropics.
The tropospheric air originating from the NH extratropics shows younger mean AoA during boreal summer (JJA) mainly in the NH (negative anomalies in Fig. $6 \mathrm{~g}$ ) leading to the flushing with fresh air and the propagation of young air upward and southward to the global stratosphere in the following seasons. Mean AoA patterns from the SH extratropics show a lot of similarities to those from the NH extratropics with a 6-month shift. The young tropospheric air originating from the SH extratropics starts filling the UTLS from austral summer (DJF) in the SH and is transported upwards and northwards in the following seasons. Besides the similarities, SH-extratropical-origin air shows an old layer (about 20 months) around the $\mathrm{NH}$ extratropical tropopause (around the altitude range of 320-350 K) during JJA (Fig. 6h) linked to the flushing of the $\mathrm{NH}$ lowermost stratosphere with $\mathrm{NH}$ extratropical air (Fig. 1g). This old layer also exists in the distribution of tropical-origin air over high-latitude regions (Fig. 6i).

Beyond these known features, some interesting asymmetries of the cross-hemispheric transport can be diagnosed. Comparing the left and middle column of Fig. 6, we find that the age of SH-extratropical-origin air in the $\mathrm{NH}$ is younger than the age of $\mathrm{NH}$-extratropical-origin air in the $\mathrm{SH}$, associated with the fast flushing of the NH lower stratosphere with young air in summer (Hegglin and Shepherd, 2007; Bönisch et al., 2009; Orbe et al., 2016; Konopka et al., 2017). The latitudinal mean AoA gradients in the tropical upper troposphere are weak because of the increased latitudinal transport caused by the upper branch of the Hadley circulation and isentropic mixing. The latitudinal mean AoA gradients of the NH extratropical tracer in the SH during JJA are larger than those of the $\mathrm{SH}$ extratropical tracer in the $\mathrm{NH}$ during DJF caused by the stronger barrier along the jet in the SH during austral winter.

\section{Pathways of inter-hemispheric transport}

In Sect. 3, we discussed the transport from the three source regions based on zonal mean results. Clear hemispheric asymmetry features of transport were noticed in AMFs and age spectra. The transit time from the SH extratropical surface to the NH is shorter than that from the NH extratropical surface to the SH. The contributions (AMFs) of the NH extratropical air to the global UTLS are around 5 times larger than those from the $\mathrm{SH}$, associated with the stronger monsoons and weaker transport barriers in the NH during boreal summer, which allow strong meridional and inter-hemispheric transport. To gain deeper insights into these hemispheric asymmetries in transport, we disentangle the transport pathways in this section using zonally resolved data. Since most of the anthropogenic pollutants are emitted in the $\mathrm{NH}$ and the contributions from the $\mathrm{NH}$ extratropics to the $\mathrm{SH}$ are much larger than vice versa, the transport pathways from the $\mathrm{NH}$ to the SH are of our particular interest. 

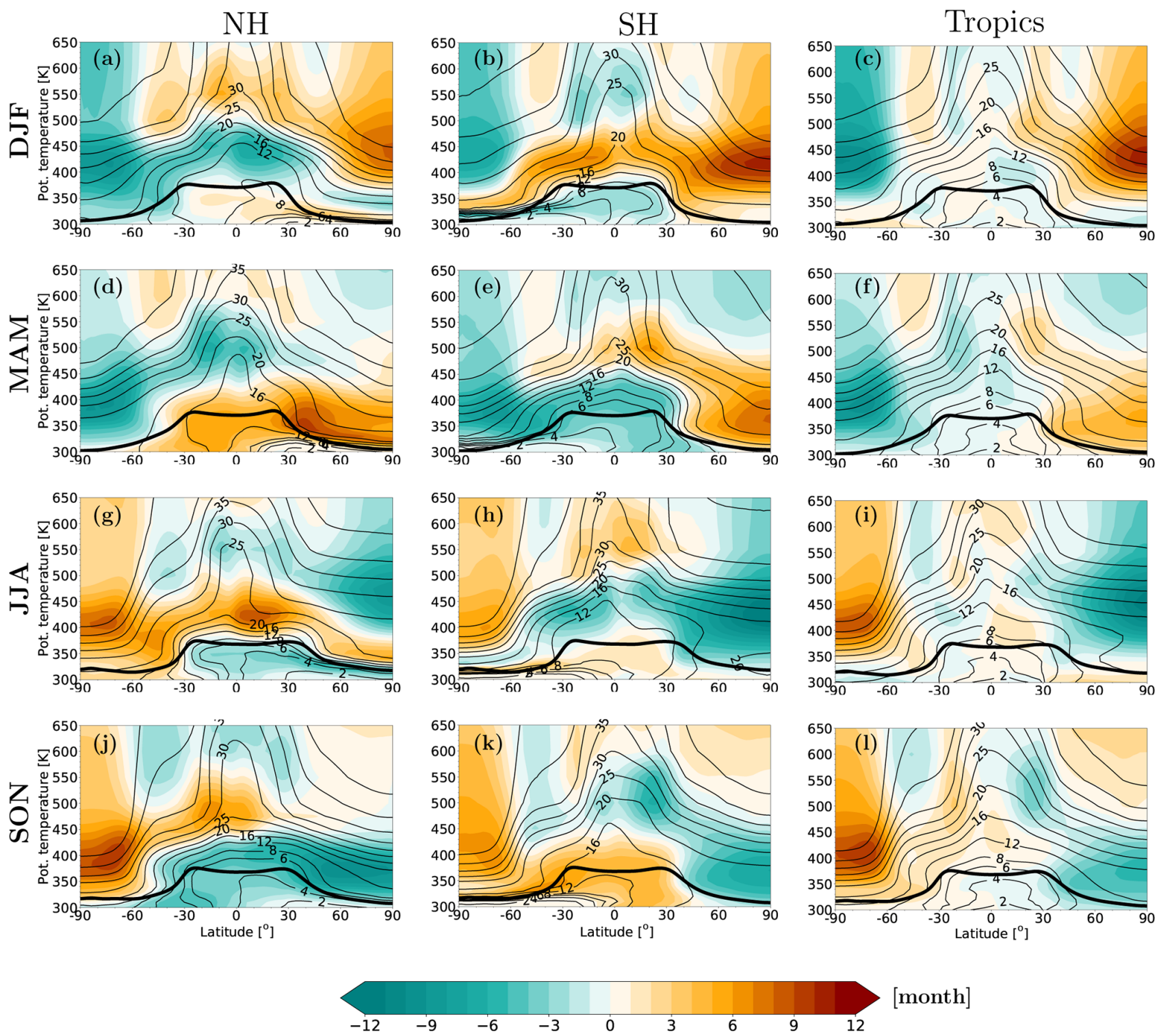

Figure 6. Climatology of the mean AoA (1999-2017, black contours) and the AoA anomaly with respect to this climatology (color shading) from the $\mathrm{NH}$ extratropics, $\mathrm{SH}$ extratropics, and tropics for each season. The black line shows the WMO tropopause.

The monthly evolution of young air (AoA less than 3 months) from the $\mathrm{NH}$ extratropics for the longitudepressure cross section along the latitude of $10^{\circ} \mathrm{S}$ is illustrated in Fig. 7. We choose $10^{\circ} \mathrm{S}$ to reduce the influence of reversible transport across the Equator. The AMF from January to May is nearly 0 , and therefore only May is shown (Fig. 7a), which is different from the previous results (e.g., Holzer, 2009, their Fig. 3; Orbe et al., 2016, their Fig. 5a-e). This difference is likely caused by the model setup in our simulations with the species set to 0 in the boundary layer outside of the source region in each time step, which eliminates the cross-equatorial transport from the $\mathrm{NH}$ extratropical surface to the ITCZ region in the boundary layer and then ascent over the tropics and SH subtropics. The convection in boreal winter is not strong enough to lift abundant $\mathrm{NH}$ extratropical air to high altitude for isentropic transport in the UTLS, which suggests the lack of inter-hemispheric transport driven by convective divergent outflow during winter. First significant signatures become evident in June-July, reach maximum in August-September, and vanish in November. There is almost no inter-hemispheric exchange in the lower troposphere. Despite the model setup, this is probably related to stable easterlies, which are less disturbed by Kelvin waves and which effectively act as a meridional transport barrier.

Young air masses from the $\mathrm{NH}$ extratropics are transported to the SH from June to October (Fig. 7b-f) mainly along two distinct pathways: between 0 and $120^{\circ} \mathrm{E}$ (denoted as the ASM region) in the altitude range of 340- 

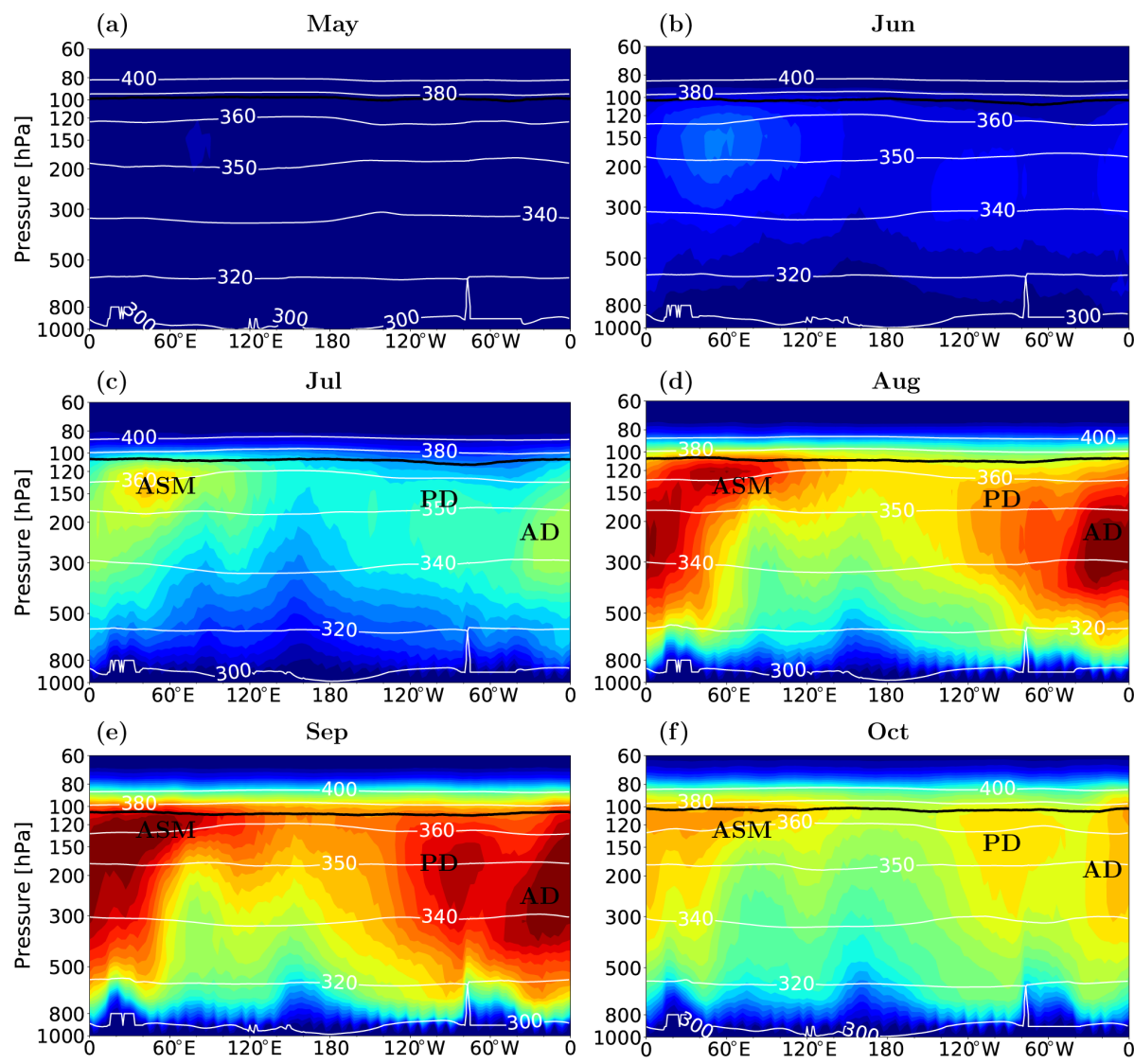

(f)

Oct
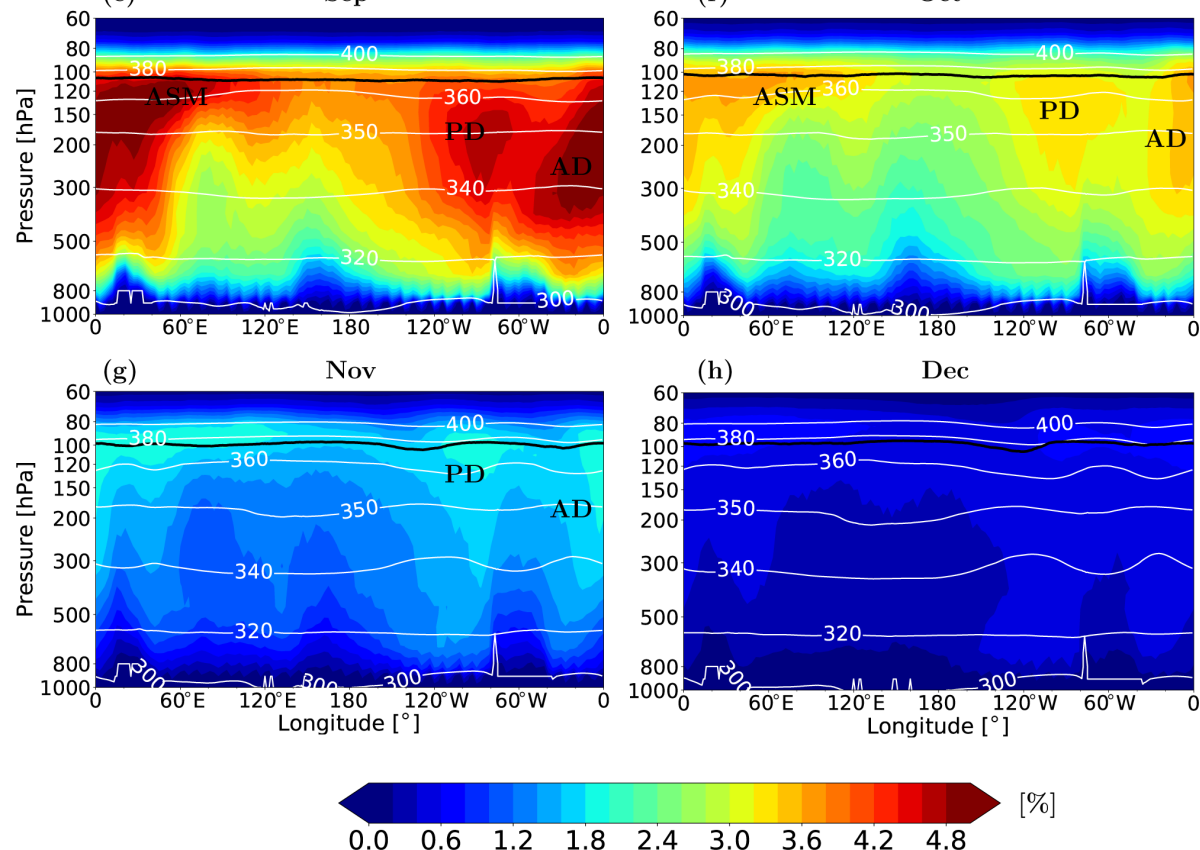

Figure 7. Longitude-pressure cross section along the latitude of $10^{\circ} \mathrm{S}$ of monthly mean $\mathrm{NH}$ extratropical young ( $<3$ months) AMF (color shading) during 1999-2017. White lines show isentropic levels; the black line shows the WMO tropopause. ASM, PD, and AD respectively indicate the rough locations of the Asian summer monsoon region, Pacific westerly ducts, and the Atlantic westerly ducts.

$390 \mathrm{~K}$ and above the Atlantic (around $20^{\circ} \mathrm{W}$ ) and Pacific (around $80^{\circ} \mathrm{W}$ ), denoted as regions of westerly ducts (AD and PD for Atlantic and Pacific ducts, respectively). The cross-equatorial transport over the Atlantic and Pacific peaks at lower altitudes mainly in the upper troposphere between 340 and $350 \mathrm{~K}$ compared to the cross-hemispheric transport over the ASM region. The relative importance of the interhemispheric transport through the ASM pathway compared to those over the Atlantic and Pacific seems to be stronger in our study than in Orbe et al. (2016, c.f. their Fig. $5 f-j$ ). To disentangle which flow properties in the $\mathrm{NH}$ cause this pattern of inter-hemispheric exchange, zonally revolved views of both the AMF (less than 3 months) and the zonal wind overplotted with potential vorticity (PV) contours are shown in Figs. 8 and 9, respectively. Here, monthly means (July, September, and November) of young AMF are plotted at 340 and $360 \mathrm{~K}$ potential temperature levels. We still stick to our simplified notation (UTLS); even a significant part of transport occurs within the TTL. 


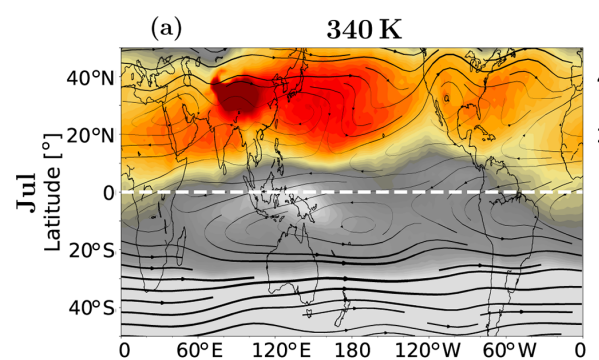

(c)

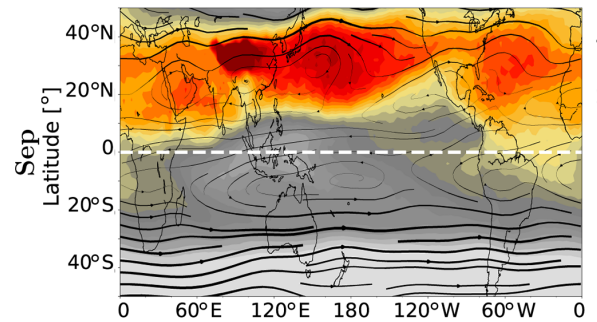

(e)

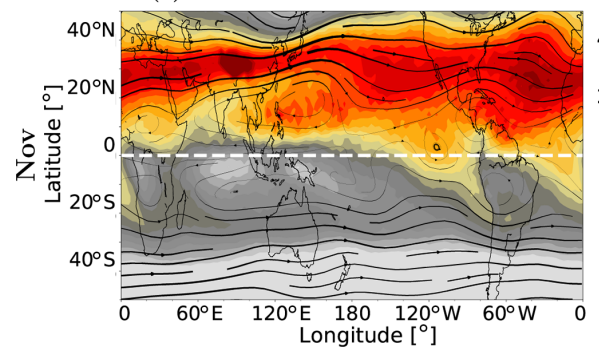

(b)

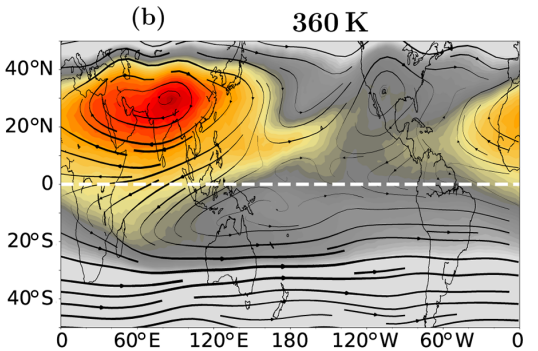

(d)

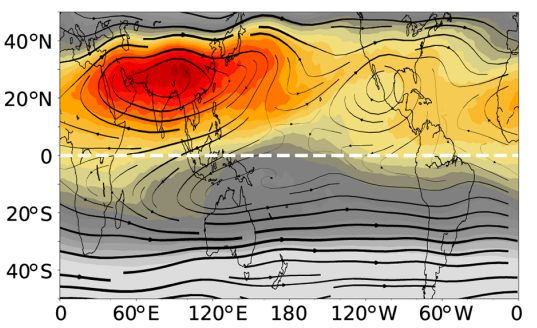

(f)

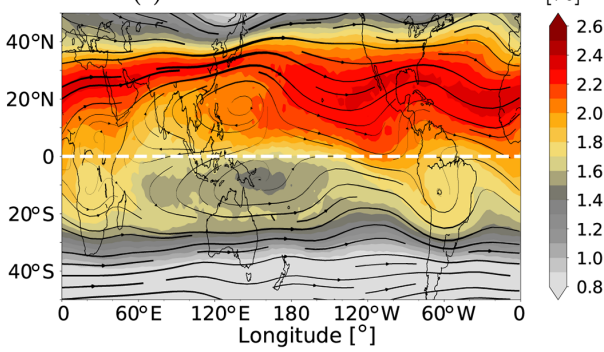

Figure 8. A snapshot of the horizontal distribution of the NH-extratropical-origin young ( $<3$ months) air on the 340 and $360 \mathrm{~K}$ isentropic surface during July, September, and November. Streamlines show horizontal winds.

Figure 8 shows that the time evolution of the AMF crossing the Equator is caused by the combination of two dynamical processes: (i) ASM anticyclonic flow and related eddy shedding, mainly at $\theta=360 \mathrm{~K}$ (Popovic and Plumb, 2001; Orbe et al., 2016), and (ii) the eastward-propagating Rossby wave dynamics across the Equator in regions of westerly winds (westerly ducts), mainly over the Pacific and the Atlantic. In July, the peak of the young air (less than 3 months) at $340 \mathrm{~K}$ is located over the Tibetan Plateau and is related to the elevated orography over Tibet, which is very close to the $340 \mathrm{~K}$ level, so the peak is strongly affected by the released boundary tracers. A second peak is located in the subtropics of the western Pacific and can be attributed to the outflow from the monsoon circulation at a lower level. The ASM circulation keeps supplying the $\mathrm{NH}$ extratropical young air from a lower level (Fig. 8a and c) and isolates most of the young air inside the center of the ASM anticyclone at $360 \mathrm{~K}$ (Fig. 8b and d) during July-September. Part of the NH-extratropicalorigin air which was entrained into the ASM anticyclone moves southward and westward along with the ASM circulation and is then transported to the SH by eddy shedding detaching ASM air from the anticyclone and subsequently being transported into the SH (Orbe et al., 2016, their Fig. 7) and to the Atlantic by the easterly flow on the southern edge of the ASM anticyclone.

The westerly ducts can be clearly seen in the respective climatology of the zonal wind and PV shown in Fig. 9. The existence of westerly ducts is altitude dependent. The tongues of PV and the related anomalies of the westerly wind can be diagnosed in the $\mathrm{NH}$, over both the Pacific and the Atlantic, from July to November at the potential temperature level of $360 \mathrm{~K}$, while at $340 \mathrm{~K}$ westerly ducts only appear in boreal autumn and winter (starting from October; not shown). Note that the westerlies in the $\mathrm{NH}$ become stronger from July to November. The impact of the westerly ducts on the crosshemispheric transport can be deduced from the time evolution of the AMF at $340 \mathrm{~K}$ (Fig. 8a, c, and e) with some distinct signatures over the Atlantic and slightly weaker signatures over the Pacific. Although the westerly ducts do not exist in July and September at $340 \mathrm{~K}$, weak westerlies at levels below allow cross-equatorial transport over the Atlantic.

The picture changes at $\theta=360 \mathrm{~K}$ (Fig. 8b, d, and f). While the eddy shedding mechanism plays an important role from July to September, there is only weak transport from the NH to the tropics and to the SH through the westerly ducts during this time. This implies the important role of the ASM circulation in the asymmetry of inter-hemispheric transport 


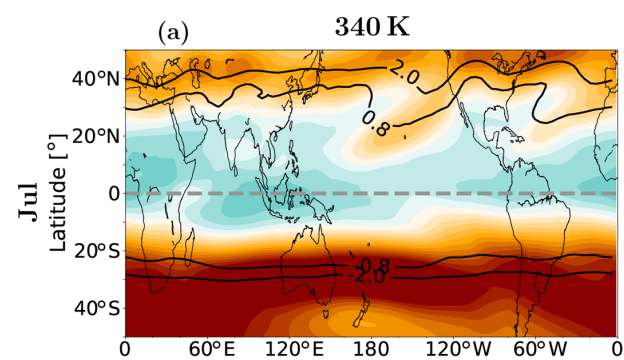

(c)

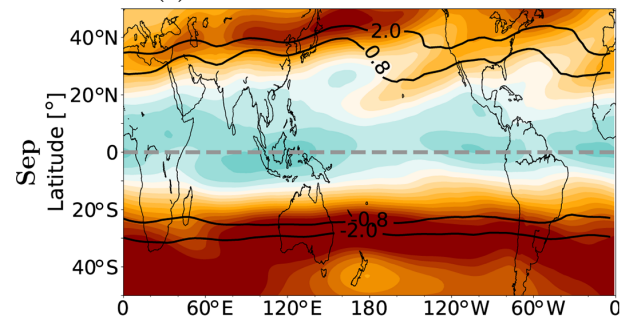

(e)

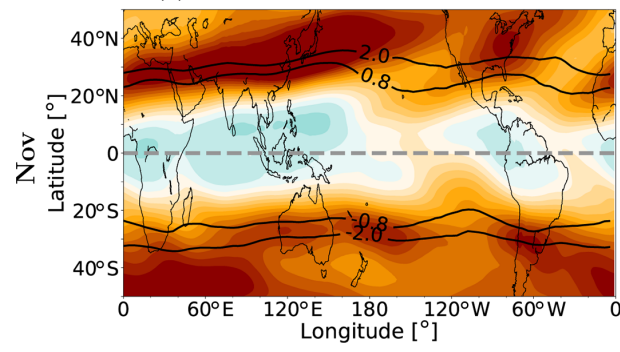

(b)

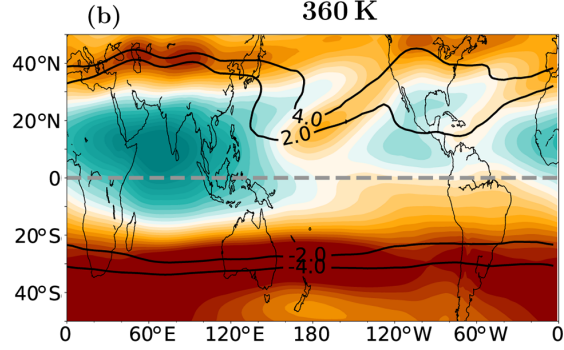

(d)

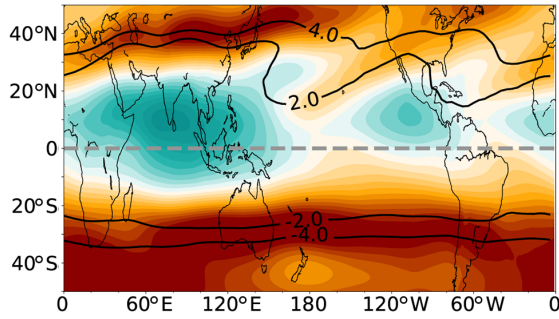

(f)

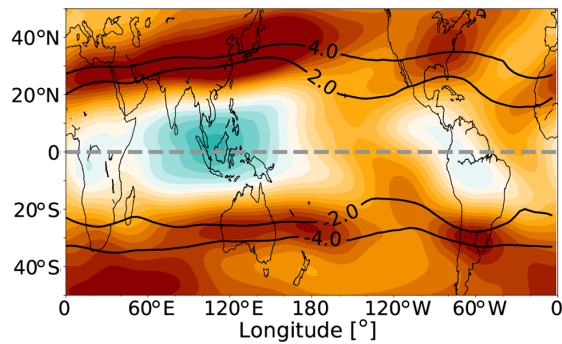

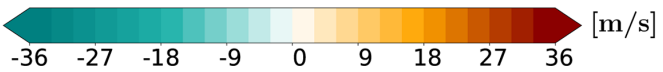

Figure 9. Climatological (1999-2017) horizontal distribution of zonal wind on the 340 and $360 \mathrm{~K}$ isentropic surface during July, September, and November. The potential vorticity is indicated by the black contours.

at the $360 \mathrm{~K}$ level. However, starting from September, the westerly ducts start to drive the cross-hemispheric transport (Fig. 8d and f). On the one hand, the westerly ducts are getting stronger in boreal autumn and winter (Fig. 9d and f) compared to boreal summer (Fig. 9b). On the other hand, most of the tracers transported across the Equator through the westerly ducts originate from ASM regions following the evolution of the ASM anticyclone. This suggests that the westerly ducts alone would not transport a substantial amount of young air masses from the $\mathrm{NH}$ extratropics to the SH. Significant inter-hemispheric transport through westerly ducts only happens when the $\mathrm{NH}$ extratropical air has been transported into the UTLS by the ASM aforehand. Hence, it is the interplay between the ASM anticyclone and the westerly ducts which drives the inter-hemispheric transport from boreal summer to autumn.

The monthly evolution of zonal winds along the Equator and young AMF from the $\mathrm{NH}$ extratropics over the region of $\left[6^{\circ} \mathrm{N}, 20^{\circ} \mathrm{N}\right]$ are illustrated in Fig. 10. Only the results from every second month are shown here to reduce the redundancy. Westerly ducts in the UTLS (350-380 K) are strongest in January and weakest in September. However, we find that the largest inter-hemispheric transport happens in September (Fig. 7e) with neither the strongest ASM nor the strongest westerly ducts. Figure 10 shows that the largest amount of $\mathrm{NH}$ extratropical air (highest AMFs) is transported to the UTLS over the southern ASM region, Pacific, and Atlantic in September by the ASM circulation and eddy shedding before crossing the Equator. And they are larger than the AMFs in July (strongest ASM) and in January (strongest westerly ducts), which again suggests that neither the westerly ducts nor the ASM alone determine cross-equatorial transport. We examine the monthly evolution of young ( $<3$ months) AMFs from the $\mathrm{NH}$ extratropics on the isentropic surface between 340 and $420 \mathrm{~K}$ from May to December (not shown) and notice that the coupling effect between ASM and westerly ducts is time and altitude dependent. The interaction between ASM and westerly ducts mainly drives the inter-hemispheric transport during autumn in the UTLS due to the coincidence of the westerly ducts and a significant amount of NH air at UTLS levels, which was transported upwards by the ASM during the previous months. This coupling effect plays an important role in the inter-hemispheric transport from summer to autumn at the altitude level between 350 and $370 \mathrm{~K}$. 
(a)

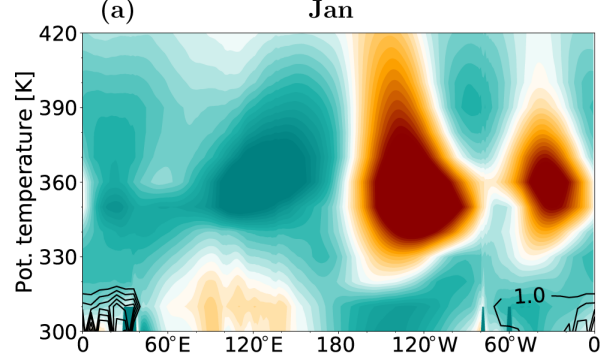

(c)

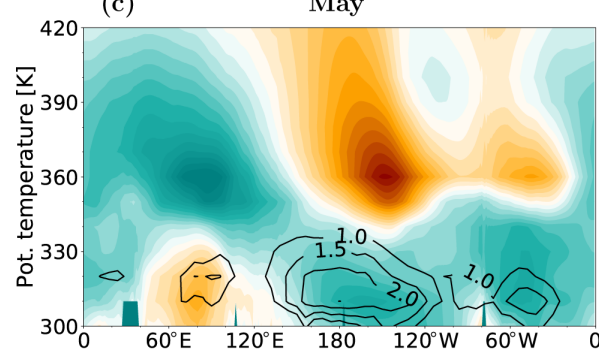

(e)

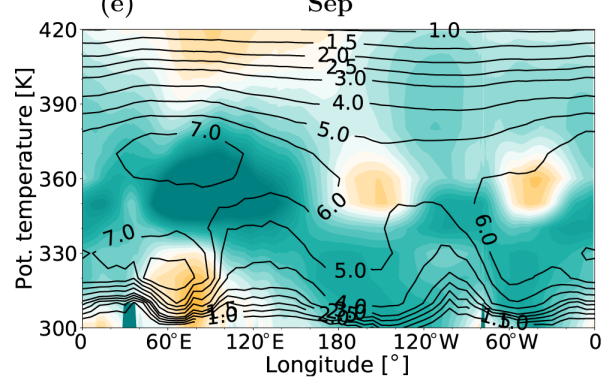

(b)

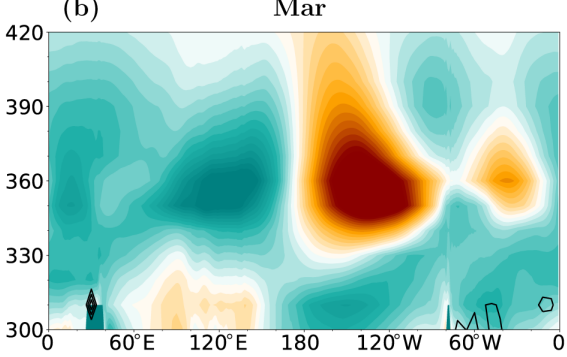

(d)

Jul
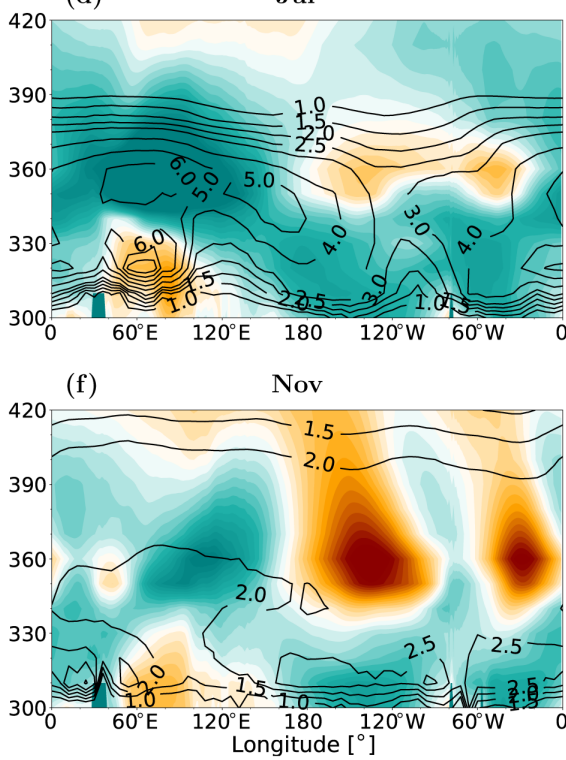

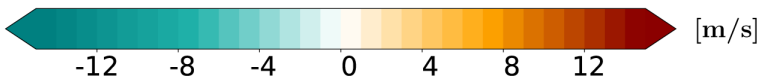

Figure 10. Longitude-potential-temperature cross section along the Equator of monthly mean zonal wind overplotted with the monthly zonal mean of $\mathrm{NH}$ extratropical young (<3 months) AMF (contours) over the domain of $\left[6^{\circ} \mathrm{N}, 20^{\circ} \mathrm{N}\right]$ during $1999-2017$.

\section{Discussion}

The air contributions and age spectrum (or AoA) from different source regions to the destination regions in the atmosphere provide valuable information for understanding the effect of natural and anthropogenic emissions on the atmospheric composition and climate. However, recent studies show substantial transport uncertainties depending on the methods, models, and meteorological reanalyses used (e.g., Krol et al., 2018; Ploeger et al., 2019).

Recently, Hauck et al. (2020) estimated the age spectra and AMF also using simulations from CLaMS but with the pulse tracers released from the tropopause level over the NH extratropics $\left(30-90^{\circ} \mathrm{N}\right)$, SH extratropics $\left(30-90^{\circ} \mathrm{S}\right)$, and tropics $\left(30^{\circ} \mathrm{S}-30^{\circ} \mathrm{N}\right)$. The first obvious difference to our results is that the NH-extratropical and SH-extratropical-origin air pulsed in the boundary layer contributes much less to the lower stratosphere compared to air originating at tropopause level (Hauck et al., 2020, their Fig. 2). However, the trac- ers pulsed at the tropopause level are more latitudinally confined compared to the results here. Furthermore, the interhemispheric transport is more symmetric and nearly negligible based on the pulse tracers from the tropopause, while the tracers pulsed from the boundary layer show substantial inter-hemispheric transport, especially from the $\mathrm{NH}$ extratropics to the $\mathrm{SH}$. This is presumable because the hemispheric differences in transport mainly result from the hemispheric asymmetry of the upward motion of the Hadley circulation in boreal and austral summer; of the land-sea distribution; and of the orography, whose importance decreases with altitude. Note that the strongest cross-hemispheric transport from the $\mathrm{NH}$ extratropics to the $\mathrm{SH}$ was diagnosed here below the tropopause at potential temperature levels 340 and $360 \mathrm{~K}$. As recently discussed in Yan et al. (2019), the Asian and North American summer monsoon tracers released at a lower level (350-360 K) and upper level (370-380 K) show similar results, with upper-level tracers being more confined 
in the $\mathrm{NH}$ and with lower-level tracers significantly crossing the Equator.

The age spectra with respect to the $\mathrm{NH}$ extratropical tropopause in the high-latitude lower stratosphere (Hauck et al., 2020, their Fig. 3) show a less distinct multimodal shape with much weaker seasonality compared to spectra with respect to the NH extratropical boundary layer, which are strongly affected by the seasonal variation (Fig. 5a). The age spectra for the $\mathrm{NH}$ extratropical boundary origin at $60^{\circ} \mathrm{N}$ on the $360 \mathrm{~K}$ surface peak at about 2-month larger transit times compared to age spectra related to the tropopause due to the extra vertical transport from the boundary layer to the tropopause. Both the NH extratropical boundary air and the NH extratropical tropopause air in the NH high-latitude lower stratosphere originate at the respective surface in early summer.

AMFs from the planetary boundary layer to the troposphere were calculated by Orbe et al. (2015) using simulations from the Goddard Earth Observing System Chemistry Climate Model (GEOSCCM). They divided the Earth into $\mathrm{NH}, \mathrm{SH}$, and tropics regions, corresponding to $10-90^{\circ} \mathrm{N}, 10$ $90^{\circ} \mathrm{S}$, and $10^{\circ} \mathrm{S}-10^{\circ} \mathrm{N}$, respectively. Although the domains are different to our choice here, the seasonality in the transport patterns of AMFs (their Fig. 3) shows some similarities to our results in the UTLS (Fig. 1), e.g., the AMFs originating from the $\mathrm{NH}$ and $\mathrm{SH}$ being transported upward mainly in summer and autumn and clear influence of the Hadley cell on the tropical origin AMFs. Despite the similarities, significant differences are found between Orbe et al. (2015) and our study. Their results show that the AMFs from the NH to the global lower stratosphere are comparable to the corresponding contributions from the SH (their Figs. 2 and 3), while we find that the contributions from the NH extratropics to the global lower stratosphere are about 5 times larger than those from the SH extratropics. Hence, the asymmetric features of transport between $\mathrm{NH}$ and $\mathrm{SH}$ are more significant in middle-high-latitude regions. The contributions from the $\mathrm{NH}$ and SH surface (tropics) to the atmosphere in their study are much higher (lower) than the results presented here. Crossing the subtropical tropopause transport for SH origin air happens in DJF in their study instead of MAM here. These differences are mainly attributed to the different ranges of the origin regions, the different model setup for the air mass origin in the boundary layer, and the different parameterized processes in GEOSCCM and CLaMS such as convection.

A different model setup in the boundary layer from previous studies (e.g., Orbe et al., 2016, their Fig. 5) allows us to separate the contributions from different pathways in the boundary layer and the upper level. The inter-hemispheric transport from the $\mathrm{NH}$ extratropics to the $\mathrm{SH}$ during boreal winter just happens in the boundary layer, mainly caused by the convergence from the $\mathrm{NH}$ extratropical surface to the ITCZ region, and then the air is transported upward and southward by Hadley and BD circulations. There is almost no inter-hemispheric transport driven by the convective outflow at high altitude during boreal winter. The cross-equatorial transport from the NH extratropics to the SH during boreal summer and autumn through UTLS is comparable to the inter-hemispheric transport through the boundary layer. Simulations from a two-box model show that the transit time of the $\mathrm{NH}$-origin air to the $\mathrm{SH}$ is shorter than vice versa associated with the different strength of the seasonal cycle and the asymmetric position of the ITCZ (Chen et al., 2017; Krol et al., 2018). However, our simulations based on three source domains show that the mean AoA from the NH extratropical surface to the SH is longer than vice versa (Fig. 6). The discrepancy is mainly caused by different definitions of the domains, which are $30-90^{\circ} \mathrm{N}$ and $30-90^{\circ} \mathrm{S}$ in our study, while Chen et al. (2017) and Krol et al. (2018) define the whole hemisphere to represent the NH and SH. Hence, caution should be taken regarding the asymmetric transit time.

\section{Conclusions}

This paper presents AMFs and age spectra with respect to the different surface latitude bands: $\mathrm{NH}$ extratropics $\left(30-90^{\circ} \mathrm{N}\right)$, $\mathrm{SH}$ extratropics $\left(30-90^{\circ} \mathrm{S}\right)$, and tropics $\left(30^{\circ} \mathrm{S}-30^{\circ} \mathrm{N}\right)$ source regions. The CLaMS model is used for carrying out simulations covering the period 1989-2017. We find that air originating at the $\mathrm{NH}$ extratropical surface shows about 5 times larger amounts in the UTLS compared to air from the SH surface. Although the tropical-origin air dominates the atmosphere, the amplitude of seasonal variation is comparable for transport from the tropics and from the $\mathrm{NH}$ extratropics.

Both the SH extratropical and NH extratropical age spectra show more pronounced seasonality compared to the seasonality of tropical age spectra. Air in the northern high-latitude regions originating from the $\mathrm{NH}$ extratropics is mainly transported into the UTLS from early summer to autumn, making this season particularly important for transport of anthropogenic pollutants into high-latitude regions. The transit time of $\mathrm{NH}$-extratropical-origin air to the $\mathrm{SH}$ extratropics is longer than vice versa, although the ASM helps to reduce this transit time.

Further analyses suggest that the cross-hemispheric transport of fresh air (AoA less than 3 months) from the NH extratropics to the SH mainly occurs in the altitude range of $320-420 \mathrm{~K}$. The ASM circulation has been recognized as an important driver for cross-hemispheric transport in simulations (e.g., Orbe et al., 2016) and observations, i.e., aerosol data from a wildfire plume (e.g., Kloss et al., 2019) and volcanic plume (e.g., Wu et al., 2017). In agreement with these previous studies, we confirm the crucial role of the ASM circulation during summer in causing the cross-equatorial transport. The westerly ducts have been reported as another driver of inter-hemispheric transport during winter (e.g., Webster and Holton, 1982; Tomas and Webster, 1994). Here, we find that the westerly ducts during summer and autumn also allow inter-hemispheric transport, although they are much weaker 
than during winter. However, it is neither the ASM circulation nor the westerly ducts alone but the interplay between ASM and westerly ducts that matters for the interhemispheric transport from summer to autumn in the UTLS between 350 and $370 \mathrm{~K}$. In particular, it is not the region of strongest westerly ducts (Pacific) which allows the strongest transport but the Atlantic region, where the westerlies are weaker but which is closer to the ASM, coupling with the ASM and causing strongest cross-equatorial transport.

Data availability. The CLaMS model output may be obtained from the authors upon request.

Author contributions. XY analyzed the data. FP carried out the model simulations. PK and FP contributed to the design of the analysis. MH contributed code for the analysis. PK, FP, MH, and AP provided helpful discussions and comments. XY wrote the paper with contributions from all co-authors.

Competing interests. The authors declare that they have no conflict of interest.

Acknowledgements. We thank the ECMWF for providing ERAInterim meteorological reanalysis data for this study. We gratefully acknowledge the computing time for the CLaMS simulations granted through VSR project ID JICG11 on the supercomputer JURECA at Forschungszentrum Jülich. The authors would also like to thank Darryn Waugh and the three anonymous reviewers for their very insightful comments.

Financial support. This research has been supported by the National Key Research and Development Program of China (grant no. 2018YFC1505703), National Natural Science Foundation of China project (grant nos. 41905040, 91837311, and 91937302), and a joint DFG-NSFC research project (DFG grant no. 392169209 and NSFC grant no. 20171352419). Felix Ploeger was funded by the Helmholtz Association under grant no. VH-NG-1128 (Helmholtz Young Investigators Group A-SPECi).

Review statement. This paper was edited by Farahnaz Khosrawi and reviewed by two anonymous referees.

\section{References}

Bönisch, H., Engel, A., Curtius, J., Birner, Th., and Hoor, P.: Quantifying transport into the lowermost stratosphere using simultaneous in-situ measurements of $\mathrm{SF}_{6}$ and $\mathrm{CO}_{2}$, Atmos. Chem. Phys., 9, 5905-5919, https://doi.org/10.5194/acp-9-5905-2009, 2009.

Bowman, K. P.: Transport of carbon monoxide from the tropics to the extratropics, J. Geophys. Res.-Atmos., 111, D02107, https://doi.org/10.1029/2005JD006137, 2006.

Bowman, K. P. and Carrie, G. D.: The Mean-Meridional Transport Circulation of the Troposphere in an Idealized GCM, J. Atmos. Sci., 59, 1502-1514, https://doi.org/10.1175/15200469(2002)059<1502:TMMTCO>2.0.CO;2, 2002.

Bowman, K. P. and Cohen, P. J.: Interhemispheric Exchange by Seasonal Modulation of the Hadley Circulation, J. Atmos. Sci., 54, 2045-2059, https://doi.org/10.1175/15200469(1997)054<2045:IEBSMO>2.0.CO;2, 1997.

Butchart, N.: The Brewer-Dobson circulation, Rev. Geophys., 52, 157-184, https://doi.org/10.1002/2013RG000448, 2014.

Chen, G., Orbe, C., and Waugh, D.: The role of monsoonlike zonally asymmetric heating in interhemispheric transport, J. Geophys. Res.-Atmos., 122, 3282-3298, https://doi.org/10.1002/2016JD026427, 2017.

Czeplak, G. and Junge, C.: Studies of Interhemispheric Exchange in the Troposphere by a Diffusion Model, in: International Union of Theoretical and Applied Mechanics and International Union of Geodesy and Geophysics, vol. 18 of Advances in Geophysics, edited by: Frenkiel, F. and Munn, R., Elsevier, 57-72, https://doi.org/10.1016/S0065-2687(08)60571-3, 1975.

Dee, D. P., Uppala, S. M., Simmons, A. J., Berrisford, P., Poli, P., Kobayashi, S., Andrae, U., Balmaseda, M. A., Balsamo, G., Bauer, P., Bechtold, P., Beljaars, A. C. M., van de Berg, L., Bidlot, J., Bormann, N., Delsol, C., Dragani, R., Fuentes, M., Geer, A. J., Haimberger, L., Healy, S. B., Hersbach, H., Holm, E. V., Isaksen, L., Kallberg, P., Koehler, M., Matricardi, M., McNally, A. P., Monge-Sanz, B. M., Morcrette, J.-J., Park, B.-K., Peubey, C., de Rosnay, P., Tavolato, C., Thepaut, J.-N., and Vitart, F.: The ERA-Interim reanalysis: configuration and performance of the data assimilation system, Q. J. Roy. Meteorol. Soc., 137, 553597, https://doi.org/10.1002/qj.828, 2011.

Denning, A. S., Holzer, M., Gurney, K. R., Heimann, M., Law, R. M., Rayner, P. J., Fung, I. Y., Fan, S.-M., Taguchi, S., Friedlingstein, P., Balkanski, Y., Taylor, J., Maiss, M., and Levin, I.: Three-dimensional transport and concentration of $\mathrm{SF}_{6} \mathrm{~A}$ model intercomparison study (TransCom 2), Tellus B, 51, 266297, https://doi.org/10.3402/tellusb.v51i2.16286, 1999.

Dlugokencky, E. J., Bruhwiler, L., White, J. W. C., Emmons, L. K., Novelli, P. C., Montzka, S. A., Masarie, K. A., Lang, P. M., Crotwell, A. M., Miller, J. B., and Gatti, L. V.: Observational constraints on recent increases in the atmospheric $\mathrm{CH}_{4}$ burden, Geophys. Res. Lett., 36, L18803, https://doi.org/10.1029/2009GL039780, 2009.

Engel, A., Möbius, T., Bönisch, H., Schmidt, U., Heinz, R., Levin, I., Atlas, E., Aoki, S., Nakazawa, T., Sugawara, S., Moore, F., Hurst, D., Elkins, J., Schauffler, S., Andrews, A., and Boering, K.: Age of stratospheric air unchanged within uncertainties over the past 30 years, Nat. Geosci., 2, 28-31, https://doi.org/10.1038/ngeo388, 2009.

Engel, A., Bönisch, H., Ullrich, M., Sitals, R., Membrive, O., Danis, F., and Crevoisier, C.: Mean age of stratospheric air derived 
from AirCore observations, Atmos. Chem. Phys., 17, 68256838, https://doi.org/10.5194/acp-17-6825-2017, 2017.

Erukhimova, T. and Bowman, K. P.: Role of convection in globalscale transport in the troposphere, J. Geophys. Res.-Atmos., 111, D03105, https://doi.org/10.1029/2005JD006006, 2006.

Francey, R. J. and Frederiksen, J. S.: The 2009-2010 step in atmospheric $\mathrm{CO}_{2}$ interhemispheric difference, Biogeosciences, 13, 873-885, https://doi.org/10.5194/bg-13-873-2016, 2016.

Fritsch, F., Garny, H., Engel, A., Bönisch, H., and Eichinger, R.: Sensitivity of age of air trends to the derivation method for nonlinear increasing inert $\mathrm{SF}_{6}$, Atmos. Chem. Phys., 20, 8709-8725, https://doi.org/10.5194/acp-20-8709-2020, 2020.

Fueglistaler, S., Dessler, A. E., Dunkerton, T. J., Folkins, I., Fu, Q., and Mote, P. W.: Tropical tropopause layer, Rev. Geophys., 47, RG1004, https://doi.org/10.1029/2008RG000267, 2009.

Fueglistaler, S., Haynes, P. H., and Forster, P. M.: The annual cycle in lower stratospheric temperatures revisited, Atmos. Chem. Phys., 11, 3701-3711, https://doi.org/10.5194/acp11-3701-2011, 2011.

Garny, H., Birner, T., Bönisch, H., and Bunzel, F.: The effects of mixing on Age of Air, J. Geophys. Res., 119, 7015-7034, https://doi.org/10.1002/2013JD021417, 2014.

Gloor, M., Dlugokencky, E., Brenninkmeijer, C., Horowitz, L., Hurst, D. F., Dutton, G., Crevoisier, C., Machida, T., and Tans, P.: Three-dimensional $\mathrm{SF}_{6}$ data and tropospheric transport simulations: Signals, modeling accuracy, and implications for inverse modeling, J. Geophys. Res.-Atmos., 112, D15112, https://doi.org/10.1029/2006JD007973, 2007.

Haine, T. W. N., Zhang, H., Waugh, D. W., and Holzer, M.: On transit time distributions in unsteady circulation models, Ocean Model., 21, 35-45, 2008.

Hall, T. M. and Plumb, R. A.: Age as a diagnostic of stratospheric transport, J. Geophys. Res., 99, 1059-1070, 1994.

Hartley, D. E. and Black, R. X.: Mechanistic analysis of interhemispheric transport, Geophys. Res. Lett., 22, 2945-2948, https://doi.org/10.1029/95GL02823, 1995.

Hauck, M., Fritsch, F., Garny, H., and Engel, A.: Deriving stratospheric age of air spectra using an idealized set of chemically active trace gases, Atmos. Chem. Phys., 19, 5269-5291, https://doi.org/10.5194/acp-19-5269-2019, 2019.

Hauck, M., Bönisch, H., Hoor, P., Keber, T., Ploeger, F., Schuck, T. J., and Engel, A.: A convolution of observational and model data to estimate age of air spectra in the northern hemispheric lower stratosphere, Atmos. Chem. Phys., 20, 8763-8785, https://doi.org/10.5194/acp-20-8763-2020, 2020.

Hegglin, M. I. and Shepherd, T. G.: $\mathrm{O}_{3}-\mathrm{N}_{2} \mathrm{O}$ correlations from the Atmospheric Chemistry Experiment: Revisiting a diagnostic of transport and chemistry in the stratosphere, J. Geophys. Res., 112, D19301, https://doi.org/10.1029/2006JD008281, 2007.

Holton, J. R., Haynes, P., McIntyre, M. E., Douglass, A. R., Rood, R. B., and Pfister, L.: Stratosphere-troposphere exchange, Rev. Geophys., 33, 403-439, 1995.

Holzer, M.: The Path Density of Interhemispheric Surface-toSurface Transport. Part II: Transport through the Troposphere and Stratosphere Diagnosed from NCEP Data, J. Atmos. Sci., 66, 2172-2189, https://doi.org/10.1175/2009JAS2895.1, 2009.

Holzer, M., McKendry, I. G., and Jaffe, D. A.: Springtime transPacific atmospheric transport from east Asia: A transit-time probability density function approach, J. Geophys. Res.-Atmos., 108, 4708, https://doi.org/10.1029/2003JD003558, 2003.

Hoor, P., Fischer, H., and Lelieveld, J.: Tropical and extratropical tropospheric air in the lowermost stratosphere over Europe: A CO-based budget, Geophys. Res. Lett., 32, L07802, https://doi.org/10.1029/2004GL022018, 2005.

Hoskins, B. J., McIntyre, M. E., and Robertson, A. W.: On the use and significance of isentropic potential vorticity maps, Q. J. Roy. Meteor. Soc., 111, 877-946, 1985.

Jacob, D. J., Prather, M. J., Wofsy, S. C., and McElroy, M. B.: Atmospheric distribution of ${ }^{85} \mathrm{Kr}$ simulated with a general circulation model, J. Geophys. Res.-Atmos., 92, 6614-6626, https://doi.org/10.1029/JD092iD06p06614, 1987.

Kloss, C., Berthet, G., Sellitto, P., Ploeger, F., Bucci, S., Khaykin, S., Jégou, F., Taha, G., Thomason, L. W., Barret, B., Le Flochmoen, E., von Hobe, M., Bossolasco, A., Bègue, N., and Legras, B.: Transport of the 2017 Canadian wildfire plume to the tropics via the Asian monsoon circulation, Atmos. Chem. Phys., 19, 13547-13567, https://doi.org/10.5194/acp-19-135472019, 2019.

Konopka, P. and Pan, L. L.: On the mixing-driven formation of the Extratropical Transition Layer (ExTL), J. Geophys. Res., 117, D18301, https://doi.org/10.1029/2012JD017876, 2012.

Konopka, P., Steinhorst, H.-M., Grooß, J.-U., Günther, G., Müller, R., Elkins, J. W., Jost, H.-J., Richard, E., Schmidt, U., Toon, G., and McKenna, D. S.: Mixing and Ozone Loss in the 1999-2000 Arctic Vortex: Simulations with the 3-dimensional Chemical Lagrangian Model of the Stratosphere (CLaMS), J. Geophys. Res., 109, D02315, https://doi.org/10.1029/2003JD003792, 2004.

Konopka, P., Ploeger, F., Tao, M., Birner, T., and Riese, M.: Hemispheric asymmetries and seasonality of mean age of air in the lower stratosphere: Deep versus shallow branch of the Brewer-Dobson circulation, J. Geophys. Res., 120, 2053-2066, https://doi.org/10.1002/2014JD022429, 2015.

Konopka, P., Ploeger, F., Tao, M., and Riese, M.: Regionally Resolved Diagnostic of Transport: A Simplified Forward Model for $\mathrm{CO}_{2}$, J. Atmos. Sci., 74, 2689-2700, https://doi.org/10.1175/JAS-D-16-0367.1, 2017.

Kovács, T., Feng, W., Totterdill, A., Plane, J. M. C., Dhomse, S., Gómez-Martín, J. C., Stiller, G. P., Haenel, F. J., Smith, C., Forster, P. M., García, R. R., Marsh, D. R., and Chipperfield, M. P.: Determination of the atmospheric lifetime and global warming potential of sulfur hexafluoride using a three-dimensional model, Atmos. Chem. Phys., 17, 883-898, https://doi.org/10.5194/acp-17-883-2017, 2017.

Krol, M., de Bruine, M., Killaars, L., Ouwersloot, H., Pozzer, A., Yin, Y., Chevallier, F., Bousquet, P., Patra, P., Belikov, D., Maksyutov, S., Dhomse, S., Feng, W., and Chipperfield, M. P.: Age of air as a diagnostic for transport timescales in global models, Geosci. Model Dev., 11, 31093130, https://doi.org/10.5194/gmd-11-3109-2018, 2018.

Kunz, A., Konopka, P., Müller, R., and Pan, L. L.: Dynamical tropopause based on isentropic potential vorticity gradients, J. Geophys. Res., 116, D01110, https://doi.org/10.1029/2010JD014343, 2011.

Levine, J. G., Braesicke, P., Harris, N. R. P., Savage, N. S., and Pyle, J. A.: Pathways and timescales for troposphere-tostratosphere transport via the tropical layer and their relevance 
for very short-lived substances, J. Geophys. Res., 112, D04308, https://doi.org/10.1029/2005JD006940, 2007.

Li, F., Waugh, D. W., Douglass, A. R., Newman, P. A., Pawson, S., Stolarski, R. S., Strahan, S. E., and Nielsen, J. E.: Seasonal variations in stratospheric age spectra in GEOSCCM, J. Geophys. Res., 117, D05134, https://doi.org/10.1029/2011JD016877, 2012.

Liang, Q., Newman, P. A., Daniel, J. S., Reimann, S., Hall, B. D., Dutton, G., and Kuijpers, L. J. M.: Constraining the carbon tetrachloride $\left(\mathrm{CCl}_{4}\right)$ budget using its global trend and inter-hemispheric gradient, Geophys. Res. Lett., 41, 5307-5315, https://doi.org/10.1002/2014GL060754, 2014.

Lintner, B. R.: Mechanisms of passive tracer interhemispheric transport: An analysis of model-derived and observational interhemispheric transport climatology and interannual variations, $\mathrm{PhD}$ thesis, University of California, Berkeley, 2003.

Lintner, B. R., Gilliland, A. B., and Fung, I. Y.: Mechanisms of convection-induced modulation of passive tracer interhemispheric transport interannual variability, J. Geophys. Res.Atmos., 109, D13102, https://doi.org/10.1029/2003JD004306, 2004.

Maiss, M., Steele, L., Francey, R. J., Fraser, P. J., Langenfelds, R. L., Trivett, N. B., and Levin, I.: Sulfur hexafluoride-A powerful new atmospheric tracer, Atmos. Environ., 30, 1621-1629, https://doi.org/10.1016/1352-2310(95)00425-4, Special Issue: Joint 8th CAGCP and 2nd IGAC Conference on Global Atmospheric Chemistry, 1996.

McKenna, D. S., Konopka, P., Grooß, J.-U., Günther, G., Müller, R., Spang, R., Offermann, D., and Orsolini, Y.: A new Chemical Lagrangian Model of the Stratosphere (CLaMS): 1. Formulation of advection and mixing, J. Geophys. Res., 107, 4309, https://doi.org/10.1029/2000JD000114, 2002.

Müller, J.-F. and Brasseur, G.: IMAGES: A threedimensional chemical transport model of the global troposphere, J. Geophys. Res.-Atmos., 100, 16445-16490, https://doi.org/10.1029/94JD03254, 1995.

Naus, S., Montzka, S. A., Pandey, S., Basu, S., Dlugokencky, E. J., and Krol, M.: Constraints and biases in a tropospheric two-box model of OH, Atmos. Chem. Phys., 19, 407-424, https://doi.org/10.5194/acp-19-407-2019, 2019.

Orbe, C., Holzer, M., Polvani, L. M., and Waugh, D.: Air-mass origin as a diagnostic of tropospheric transport, J. Geophys. Res., 118, 1459-1470, https://doi.org/10.1002/jgrd.50133, 2013.

Orbe, C., Waugh, D. W., and Newman, P. A.: Air-mass origin in the tropical lower stratosphere: The influence of Asian boundary layer air, Geophys. Res. Lett., 42, 4240-4248, https://doi.org/10.1002/2015GL063937 2015.

Orbe, C., Waugh, D. W., Newman, P. A., and Steenrod, S.: The Transit-Time Distribution from the Northern Hemisphere Midlatitude Surface, J. Atmos. Sci., 73, 3785-3802, https://doi.org/10.1175/JAS-D-15-0289.1, 2016.

Orbe, C., Yang, H., Waugh, D. W., Zeng, G., Morgenstern , O., Kinnison, D. E., Lamarque, J.-F., Tilmes, S., Plummer, D. A., Scinocca, J. F., Josse, B., Marecal, V., Jöckel, P., Oman, L. D., Strahan, S. E., Deushi, M., Tanaka, T. Y., Yoshida, K., Akiyoshi, H., Yamashita, Y., Stenke, A., Revell, L., Sukhodolov, T., Rozanov, E., Pitari, G., Visioni, D., Stone, K. A., Schofield, R., and Banerjee, A.: Large-scale tropospheric transport in the Chemistry-Climate Model Initiative (CCMI) simulations, At- mos. Chem. Phys., 18, 7217-7235, https://doi.org/10.5194/acp18-7217-2018, 2018.

Pandey, S., Houweling, S., Krol, M., Aben, I., Monteil, G., NechitaBanda, N., Dlugokencky, E., Detmers, R., Hasekamp, O., Xu, X., Riley, W., Poulter, B., Zhang, Z., McDonald, K., White, J., Bousquet, P., and Röckmann, T.: Enhanced methane emissions from tropical wetlands during the 2011 la Niña, Sci. Rep.-UK, 7, 45759, https://doi.org/10.1038/srep45759, 2017.

Patra, P. K., Takigawa, M., Dutton, G. S., Uhse, K., Ishijima, K., Lintner, B. R., Miyazaki, K., and Elkins, J. W.: Transport mechanisms for synoptic, seasonal and interannual $\mathrm{SF}_{6}$ variations and "age" of air in troposphere, Atmos. Chem. Phys., 9, 1209-1225, https://doi.org/10.5194/acp-9-1209-2009, 2009.

Patra, P. K., Houweling, S., Krol, M., Bousquet, P., Belikov, D., Bergmann, D., Bian, H., Cameron-Smith, P., Chipperfield, M. P., Corbin, K., Fortems-Cheiney, A., Fraser, A., Gloor, E., Hess, P., Ito, A., Kawa, S. R., Law, R. M., Loh, Z., Maksyutov, S., Meng, L., Palmer, P. I., Prinn, R. G., Rigby, M., Saito, R., and Wilson, C.: TransCom model simulations of $\mathrm{CH}_{4}$ and related species: linking transport, surface flux and chemical loss with $\mathrm{CH}_{4}$ variability in the troposphere and lower stratosphere, Atmos. Chem. Phys., 11, 12813-12837, https://doi.org/10.5194/acp-11-128132011, 2011.

Patra, P. K., Krol, M. C., Montzka, S. A., Arnold, T., Atlas, E. L., Lintner, B. R., Stephens, B. B., Xiang, B., Elkins, J. W., Fraser, P. J., Ghosh, A., Hintsa, E. J., Hurst, D. F., Ishijima, K., Krummel, P. B., Miller, B. R., Miyazaki, K., Moore, F. L., Mühle, J., O’Doherty, S., Prinn, R. G., Steele, L. P., Takigawa, M., Wang, H. J., Weiss, R. F., Wofsy, S. C., and Young, D.: Observational evidence for interhemispheric hydroxyl-radical parity, Nature, 513, 219-223, https://doi.org/10.1038/nature13721, 2014.

Peters, W., Krol, M. C., Dlugokencky, E. J., Dentener, F. J., Bergamaschi, P., Dutton, G., Velthoven, P. v., Miller, J. B., Bruhwiler, L., and Tans, P. P.: Toward regional-scale modeling using the two-way nested global model TM5: Characterization of transport using $\mathrm{SF}_{6}$, J. Geophys. Res.-Atmos., 109, D19314, https://doi.org/10.1029/2004JD005020, 2004.

Ploeger, F. and Birner, T.: Seasonal and inter-annual variability of lower stratospheric age of air spectra, Atmos. Chem. Phys., 16, 10195-10213, https://doi.org/10.5194/acp-16-101952016, 2016.

Ploeger, F., Konopka, P., Walker, K., and Riese, M.: Quantifying pollution transport from the Asian monsoon anticyclone into the lower stratosphere, Atmos. Chem. Phys., 17, 7055-7066, https://doi.org/10.5194/acp-17-7055-2017, 2017.

Ploeger, F., Legras, B., Charlesworth, E., Yan, X., Diallo, M., Konopka, P., Birner, T., Tao, M., Engel, A., and Riese, M.: How robust are stratospheric age of air trends from different reanalyses?, Atmos. Chem. Phys., 19, 6085-6105, https://doi.org/10.5194/acp-19-6085-2019, 2019.

Podglajen, A. and Ploeger, F.: Retrieving the age of air spectrum from tracers: principle and method, Atmos. Chem. Phys., 19, 1767-1783, https://doi.org/10.5194/acp-19-1767-2019, 2019.

Pommrich, R., Müller, R., Grooß, J.-U., Konopka, P., Ploeger, F., Vogel, B., Tao, M., Hoppe, C. M., Günther, G., Spelten, N., Hoffmann, L., Pumphrey, H.-C., Viciani, S., D’Amato, F., Volk, C. M., Hoor, P., Schlager, H., and Riese, M.: Tropical troposphere to stratosphere transport of carbon monoxide and long-lived trace species in the Chemical Lagrangian Model of 
the Stratosphere (CLaMS), Geosci. Model Dev., 7, 2895-2916, https://doi.org/10.5194/gmd-7-2895-2014, 2014.

Popovic, J. M. and Plumb, R. A.: Eddy Shedding from the Upper-Tropospheric Asian Monsoon Anticyclone, J. Atmos. Sci., 58, 93-104, https://doi.org/10.1175/15200469(2001)058<0093:ESFTUT>2.0.CO;2, 2001.

Prather, M., McElroy, M., Wofsy, S., Russell, G., and Rind, D.: Chemistry of the global troposphere: Fluorocarbons as tracers of air motion, J. Geophys. Res., 92, 6579-6613, 1987.

Randel, W. J., Moyer, E., Park, M., Jensen, E., Bernath, P., Walker, K., and Boone, C.: Global variations of $\mathrm{HDO}$ and $\mathrm{HDO} / \mathrm{H}_{2} \mathrm{O}$ ratios in the upper troposphere and lower stratosphere derived from ACE-FTS satellite measurements, J. Geophys. Res., 117, D06303, https://doi.org/10.1029/2011JD016632, 2012.

Ratnam, J. V., Behera, S. K., and Yamagata, T.: Role of CrossEquatorial Waves in Maintaining Long Periods of Low Convective Activity over Southern Africa, J. Atmos. Sci., 72, 682-692, https://doi.org/10.1175/JAS-D-14-0063.1, 2015.

Ravishankara, A. R., Solomon, S., Turnipseed, A. A., and Warren, R. F.: Atmospheric Lifetimes of LongLived Halogenated Species, Science, 259, 194-199, https://doi.org/10.1126/science.259.5092.194, 1993.

Ray, E. A., Moore, F. L., Rosenlof, K. H., Davis, S. M., Sweeney, C., Tans, P., Wang, T., Elkins, J. W., Boenisch, H., Engel, A., Sugawara, S., Nakazawa, T., and Aoki, S.: Improving stratospheric transport trend analysis based on $\mathrm{SF}_{6}$ and $\mathrm{CO}_{2}$ measurements, $\mathrm{J}$. Geophys. Res., 119, 14110-14128, 2014.

Rosenlof, K. H.: Seasonal cycle of the residual mean meridional circulation in the stratosphere, J. Geophys. Res., 100, 5173-5191, 1995.

Schoeberl, M. R., Douglass, A. R., Polansky, B., Boone, C., Walker, K. A., and Barnath, P.: Estimation of stratospheric age spectrum from chemical tracers, J. Geophys. Res., 110, D21303, https://doi.org/10.1029/2005JD006125, 2005.

Staudt, A. C., Jacob, D. J., Logan, J. A., Bachiochi, D., Krishnamurti, T. N., and Sachse, G. W.: Continental sources, transoceanic transport, and interhemispheric exchange of carbon monoxide over the Pacific, J. Geophys. Res.-Atmos., 106, 32571-32589, https://doi.org/10.1029/2001JD900078, 2001.

Stiller, G. P., von Clarmann, T., Haenel, F., Funke, B., Glatthor, N., Grabowski, U., Kellmann, S., Kiefer, M., Linden, A., Lossow, S., and López-Puertas, M.: Observed temporal evolution of global mean age of stratospheric air for the 2002 to 2010 period, Atmos. Chem. Phys., 12, 3311-3331, https://doi.org/10.5194/acp12-3311-2012, 2012.

Tomas, R. A. and Webster, P. J.: Horizontal and Vertical Structure of Cross-Equatorial Wave Propagation, J. Atmos. Sci., 51, 1417-1430, https://doi.org/10.1175/15200469(1994)051<1417:HAVSOC>2.0.CO;2, 1994
Volk, C. M., Elkins, J. W., Fahey, D. W., Dutton, G. S., Gilligan, J. M., Loewenstein, M., Podolske, J. R., and Chan, K. R.: On the evaluation of source gas lifetimes from stratospheric observations, J. Geophys. Res., 102, 25543-25564, 1997.

Wang, K. Y. and Shallcross, D. E.: A modelling study of tropospheric distributions of the trace gases $\mathrm{CFCl}_{3}$ and $\mathrm{CH}_{3} \mathrm{CCl}_{3}$ in the 1980s, Ann. Geophys., 18, 972-986, https://doi.org/10.1007/s00585-000-0972-3, 2000.

Waugh, D. W. and Hall, T. M.: Age of stratospheric air: Theory, observations, and models, Rev. Geophys., 40, 1-27, 2002.

Waugh, D. W. and Polvani, L. M.: Climatology of intrusions into the tropical upper troposphere, Geophys. Res. Lett., 27, 3857-3860, 2000.

Waugh, D. W., Crotwell, A. M., Dlugokencky, E. J., Dutton, G. S., Elkins, J. W., Hall, B. D., Hintsa, E. J., Hurst, D. F., Montzka, S. A., Mondeel, D. J., Moore, F. L., Nance, J. D., Ray, E. A., Steenrod, S. D., Strahan, S. E., and Sweeney, C.: Tropospheric $\mathrm{SF}_{6}$ : Age of air from the Northern Hemisphere midlatitude surface, J. Geophys. Res., 118, 11429-11441, 2013.

Webster, P. J. and Holton, J. R.: Cross-Equatorial Response to Middle-Latitude Forcing in a Zonally Varying Basic State, J. Atmos. Sci., 39, 722-733, https://doi.org/10.1175/15200469(1982)039<0722:CERTML>2.0.CO;2, 1982.

WMO: Scientific assessment of ozone depletion: 2018, Global Ozone Research and Monitoring Project-Report No. 58, Geneva, Switzerland, 2018.

Wu, X., Griessbach, S., and Hoffmann, L.: Equatorward dispersion of a high-latitude volcanic plume and its relation to the Asian summer monsoon: a case study of the Sarychev eruption in 2009, Atmos. Chem. Phys., 17, 13439-13455, https://doi.org/10.5194/acp-17-13439-2017, 2017.

Wu, X., Yang, H., Waugh, D. W., Orbe, C., Tilmes, S., and Lamarque, J.-F.: Spatial and temporal variability of interhemispheric transport times, Atmos. Chem. Phys., 18, 7439-7452, https://doi.org/10.5194/acp-18-7439-2018, 2018.

Yan, X., Konopka, P., Ploeger, F., Podglajen, A., Wright, J. S., Müller, R., and Riese, M.: The efficiency of transport into the stratosphere via the Asian and North American summer monsoon circulations, Atmos. Chem. Phys., 19, 15629-15649, https://doi.org/10.5194/acp-19-15629-2019, 2019.

Yang, H., Waugh, D. W., Orbe, C., Patra, P. K., Jöckel, P., Lamarque, J.-F., Tilmes, S., Kinnison, D., Elkins, J. W., and Dlugokencky, E. J.: Evaluating Simulations of Interhemispheric Transport: Interhemispheric Exchange Time Versus $\mathrm{SF}_{6}$ Age, Geophys. Res. Lett., 46, 1113-1120, https://doi.org/10.1029/2018GL080960, 2019. 